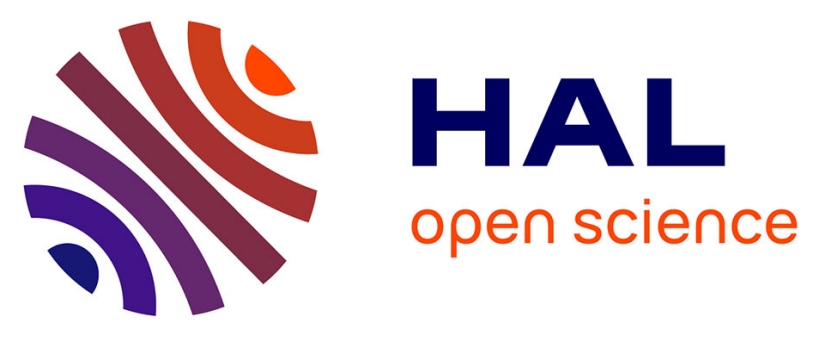

\title{
The Radical Trap in Atom Transfer Radical Polymerization Need Not Be Thermodynamically Stable. A Study of the MoX3(PMe3)3 Catalysts
}

Sébastien Maria, François Stoffelbach, José Mata, Jean-Claude Daran, Philippe Richard, Rinaldo Poli

\section{To cite this version:}

Sébastien Maria, François Stoffelbach, José Mata, Jean-Claude Daran, Philippe Richard, et al.. The Radical Trap in Atom Transfer Radical Polymerization Need Not Be Thermodynamically Stable. A Study of the MoX3(PMe3)3 Catalysts. Journal of the American Chemical Society, 2005, 127 (16), pp.5946-5956. 10.1021/ja043078e . hal-03278128

\section{HAL Id: hal-03278128 \\ https://hal.science/hal-03278128}

Submitted on 6 Jul 2021

HAL is a multi-disciplinary open access archive for the deposit and dissemination of scientific research documents, whether they are published or not. The documents may come from teaching and research institutions in France or abroad, or from public or private research centers.
L'archive ouverte pluridisciplinaire HAL, est destinée au dépôt et à la diffusion de documents scientifiques de niveau recherche, publiés ou non, émanant des établissements d'enseignement et de recherche français ou étrangers, des laboratoires publics ou privés. 


\section{The Radical Trap in Atom Transfer Radical Polymerization Need Not Be}

\section{Thermodynamically Stable. A Study of the MoX 3 (PMe 3 ) 3 Catalysts}

Sébastien Maria, ${ }^{\mathrm{a}, \mathrm{b}}$ François Stoffelbach, ${ }^{\mathrm{b}}$ José Mata, ${ }^{\mathrm{a}}$ Jean-Claude Daran, ${ }^{\mathrm{a}}$ Philippe Richard, ${ }^{\mathrm{b}}$ and Rinaldo Poli*a,b

${ }^{\mathrm{a}}$ Laboratoire de Chimie de Coordination, UPR CNRS 8241, 205 Route de Narbonne, 31077 Toulouse Cedex, France.

${ }^{\mathrm{b}}$ Laboratoire de Synthèse et d'Electrosynthèse Organométalliques, Faculté des Sciences "Mirande", Université de Bourgogne, 9 Avenue Alain Savary, BP 47870, 21078 Dijon, France

Proofs to:

Rinaldo Poli

Tel: $+33-561333195$

Fax: $+33-561553003$

E-mail: poli@Icc-toulouse.fr 


\section{Abstract}

The molybdenum(III) coordination complexes $\mathrm{MoX}_{3}\left(\mathrm{PMe}_{3}\right)_{3}(\mathrm{X}=\mathrm{Cl}, \mathrm{Br}$ and $\mathrm{I})$ are capable to control styrene polymerization under typical atom transfer radical polymerization (ATRP) conditions, in conjunction with 2-bromoethylbenzene (BEB) as an initiator. The process is accelerated by the presence of $\mathrm{Al}(\mathrm{O}-\mathrm{i}-\mathrm{Pr})_{3}$ as a co-catalyst. Electrochemical and synthetic studies aimed at identifying the nature of the spin trap have been carried out. The cyclic voltammogram of $\mathrm{MoX}_{3}\left(\mathrm{PMe}_{3}\right)_{3}(\mathrm{X}=\mathrm{Cl}, \mathrm{Br}, \mathrm{I})$ shows partial reversibility (increasing in the order $\mathrm{Cl}<\mathrm{Br}<$ I) for the one-electron oxidation wave. Addition of $\mathrm{X}^{-}$changes the voltammogram, indicating the formation of $\mathrm{MoX}_{4}\left(\mathrm{PMe}_{3}\right)_{3}$ for $\mathrm{X}=\mathrm{Cl}$ and $\mathrm{Br}$. On the other hand, $\mathrm{I}^{-}$is more easily oxidized than the $\mathrm{MoI}_{3}\left(\mathrm{PMe}_{3}\right)_{3}$ complex, thus the putative $\mathrm{MoI}_{4}\left(\mathrm{PMe}_{3}\right)_{3}$ complex is redox unstable. Electrochemical studies of $\mathrm{MoI}_{3}\left(\mathrm{PMe}_{3}\right)_{3}$ in the presence of $\mathrm{X}^{-}(\mathrm{X}=\mathrm{Cl}$ or $\mathrm{Br})$ reveal the occurrence of facile halide exchange processes, leading to the conclusion that the $\mathrm{MoI}_{3} \mathrm{X}\left(\mathrm{PMe}_{3}\right)_{3}$ products are also redox unstable. The oxidation of $\mathrm{MoX}_{3}\left(\mathrm{PMe}_{3}\right)_{3}$ with $1 / 2 \mathrm{Br}_{2}$ yields $\mathrm{MoX}_{3} \mathrm{Br}\left(\mathrm{PMe}_{3}\right)_{3}(\mathrm{X}=\mathrm{Cl}, \mathrm{Br})$, whose molecular nature is confirmed by single crystal X-ray analyses. On the other hand, the oxidation of $\mathrm{MoI}_{3}\left(\mathrm{PMe}_{3}\right)_{3}$ by $\mathrm{I}_{2}$ slowly yields a tetraiodomolybdate(III) salt of iodotrimethylphosphonium, $\left[\mathrm{Me}_{3} \mathrm{PI}\right]\left[\mathrm{MoI}_{4}\left(\mathrm{PMe}_{3}\right)_{3}\right]$, as confirmed by an X-ray study. This product has no controlling ability in radical polymerization. The redox instability of $\mathrm{MoI}_{3} \mathrm{X}\left(\mathrm{PMe}_{3}\right)_{3}$ can be reconciled with its involvement as a radical trapping species in the $\mathrm{MoI}_{3}\left(\mathrm{PMe}_{3}\right)_{3}$-catalyzed ATRP, given the second order nature of its decomposition rate. 


\section{Introduction}

Controlled radical polymerization (CRP) is attracting growing attention because it combines the advantages of radical polymerization (simplicity of operational modes, tolerance toward functional groups, ...) and "living" polymerization techniques (controlled molecular weights, narrow molecular weight distributions, functionalized chain-ends, ...). Amongst the various methods for controlling the concentration of the active radicals, atom transfer radical polymerization (ATRP) is emerging as a privileged one because it allows the use of easily available halogenated hydrocarbons as initiator and (potentially) reusable metal complexes as catalysts. The equilibrium process responsible for insuring a small active radical concentration (thus reducing dramatically the bimolecular coupling and disproportionation processes that would irreversibly consume radicals), see Scheme 1, involves transfer of a halogen atom from the halogenated initiator/dormant polymer chain to a metal complex $\mathrm{ML}_{\mathrm{n}}$ (the so-called "inner sphere electron transfer" mechanism, or ISET). The latter species is transformed into an oxidized derivative $\mathrm{X}-\mathrm{ML}_{\mathrm{n}}$ which then acts as a spin trap to regenerate the catalyst and the dormant polymer chain.

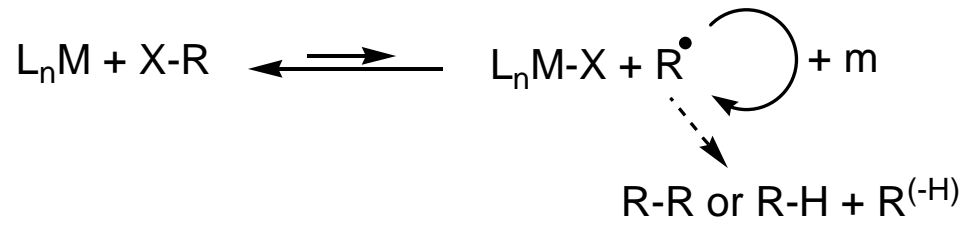

Scheme 1

After the first reports demonstrating this principle with the use of $\mathrm{Cu}^{\mathrm{I}}$ and $\mathrm{Ru}{ }^{\mathrm{II}}$ catalysts, ${ }^{[1,2]}$ ATRP processes have also been shown to occur with complexes of other ions, including $\mathrm{Ti}^{\mathrm{III}},{ }^{[3]} \mathrm{Mo}^{\mathrm{III}},{ }^{[4]} \mathrm{Re}^{\mathrm{V}},{ }^{[5]} \mathrm{Fe}^{\mathrm{II}},{ }^{[6-8]} \mathrm{Rh}^{\mathrm{I}},{ }^{[9]} \mathrm{Ni}^{\mathrm{II}},{ }^{[10]}$ and $\mathrm{Pd}^{0} .^{[11]}$ The identity of the spin trap as the proposed oxidized metal complex, containing a new metal halogen bond, has been 
supported in a few cases by the isolation and characterization of such species from parallel synthetic studies and by their use, in conjunction with free radical sources, in CRP (the socalled "reverse ATRP" conditions). However, in many other cases the chemical nature of the spin trap was not investigated, nor addressed. It is to be underlined that some of the putative spin traps have oxidation states and coordination geometries that are not paralleled by stable coordination/organometallic compounds. We have recently shown the effectiveness of halfsandwich $\mathrm{Mo}^{\mathrm{III}}$ complexes, $\mathrm{CpMoCl}_{2} \mathrm{~L}_{2}$ with $\mathrm{L}=$ phosphine or $\mathrm{L}_{2}=$ diphosphine, diene, and 1,4-diazadienes, for the ATRP of styrene and acrylates. ${ }^{[4,12,13]}$ The nature of the spin trap was suggested, at least for the $\mathrm{CpMoCl}_{2}\left(\mathrm{PMe}_{3}\right)_{2}+\mathrm{PhCHBrCH}_{3}$ initiating system, to be the 18electron product of bromine atom transfer, namely $\mathrm{CpMoCl}{ }_{2} \mathrm{Br}\left(\mathrm{PMe}_{3}\right)_{2}$. In fact, such compound was independently synthesized and shown to initiate the controlled styrene polymerization under reverse ATRP conditions (thermal decomposition of azoisobutyrronitrile, or AIBN). ${ }^{[4]}$ Attempts to isolate other 18 -electron $\mathrm{CpMoCl}_{2} \mathrm{XL}_{2}$ products, for instance with $\mathrm{L}_{2}=$ diene, however, did not succeed. ${ }^{[4]}$ A major obstacle in the furthering of these synthetic studies is the long and tedious synthetic procedure leading to the $\mathrm{CpMoCl}_{2} \mathrm{~L}_{2}$ compounds.

For this and other reasons, we have decided to extend our studies to simpler coordination compounds of $\mathrm{Mo}{ }^{\mathrm{III}}$, namely $\mathrm{MoX}_{3}\left(\mathrm{PMe}_{3}\right)_{3}(\mathrm{X}=\mathrm{Cl}, \mathrm{Br}$, I), because they are more easily synthesized and are less thermally and air sensitive than the half-sandwich compounds. Initial studies of styrene ATRP using $\mathrm{MoCl}_{3}\left(\mathrm{PMe}_{3}\right)_{3}$ were reported previously. ${ }^{[14]}$ In that study, we also demonstrated that the known ${ }^{[15]}$ tetrachloride complex, $\mathrm{MoCl}_{4}\left(\mathrm{PMe}_{3}\right)_{3}$, yields a controlled polymerization of styrene under reverse ATRP conditions, the free radicals being once again obtained from the thermal decomposition of AIBN. The molecular nature of compound $\mathrm{MoCl}_{4}\left(\mathrm{PMe}_{3}\right)_{3}$, i.e. as a neutral 7-coordinate molecule, is 
suggested by the fact that the same geometry is found by X-ray diffraction for the closely related complex $\mathrm{MoCl}_{4}\left(\mathrm{PMe}_{2} \mathrm{Ph}\right)_{3} \cdot{ }^{[16]}$

In this contribution, we extend the styrene radical polymerization studies to complexes $\mathrm{MoBr}_{3}\left(\mathrm{PMe}_{3}\right)_{3}$ and $\mathrm{MoI}_{3}\left(\mathrm{PMe}_{3}\right)_{3}$. We also demonstrate the beneficial effect of the $\mathrm{Al}(\mathrm{OiPr})_{3}$ additive for this family of catalysts. Finally, we report chemical and electrochemical oxidation studies of relevance to the chemical nature and stability of the ATRP spin trap. It will be shown that, although $\mathrm{MoI}_{3} \mathrm{X}\left(\mathrm{PMe}_{3}\right)_{3}$ complexes $(\mathrm{X}=\mathrm{Cl}, \mathrm{Br}, \mathrm{I})$ are thermodynamically unstable, they are nevertheless kinetically competent to act as spin traps for ATRP.

\section{Experimental Section}

Upon the Editor's request, all experimental procedures have been deposited as Supporting Information.

\section{Results}

(a) Styrene ATRP catalyzed by $\mathrm{MoX}_{3}\left(\mathrm{PMe}_{3}\right)_{3}(\mathrm{X}=\mathrm{Cl}, \mathrm{Br}$, I)

Complexes $\mathrm{MoX}_{3}\left(\mathrm{PMe}_{3}\right)_{3}(\mathrm{X}=\mathrm{Cl}, \mathrm{Br}, \mathrm{I})$ are capable of catalyzing the controlled polymerization of styrene under typical ATRP conditions using (1-bromoethyl)benzene (BEB) as initiator, see Figure 1. This is shown by the first order decay of the monomer concentration (indicating an approximately constant radical concentration), by the moderate molecular weights and by the relative narrow polydispersities. The polymerization with complex $\mathrm{MoCl}_{3}\left(\mathrm{PMe}_{3}\right)_{3}$ was previously studied under slightly different conditions (in bulk monomer and in $30 \% \mathrm{v} / \mathrm{v}$ solution in $\mathrm{PhCl}),{ }^{[14]}$ the results being essentially identical to those 
in toluene solution $\left(k_{\text {app }}=1.42 .10^{-4} \mathrm{~min}^{-1}\right.$ in toluene vs. $1.70 .10^{-4} \mathrm{~min}^{-1}$ in $\left.\mathrm{PhCl}\right)$. It can be noted that the polymerization has a "living" behavior for the $\mathrm{X}=\mathrm{Cl}$ and $\mathrm{Br}$ systems, as shown by the good agreement between the experimental and theoretical number-averaged molecular weights at all conversions. In addition, the polydispersity index (PDI) is relatively low at high conversions, especially with the tribromide catalyst. The higher PDI at low conversions can be explained by a slow initiation relative to the reactivation of the halogen-terminated dormant chains, a well recognized phenomenon for the ATRP of styrene initiated by BEB. ${ }^{[17]}$ For the $\mathrm{X}=\mathrm{I}$ system, on the other hand, the $\overline{\mathrm{M}_{\mathrm{n}}}$ are lower than expected and seem to reach a plateau at high conversions. This is clear indication of the intervention of catalyzed chain transfer $(\mathrm{CCT})$.
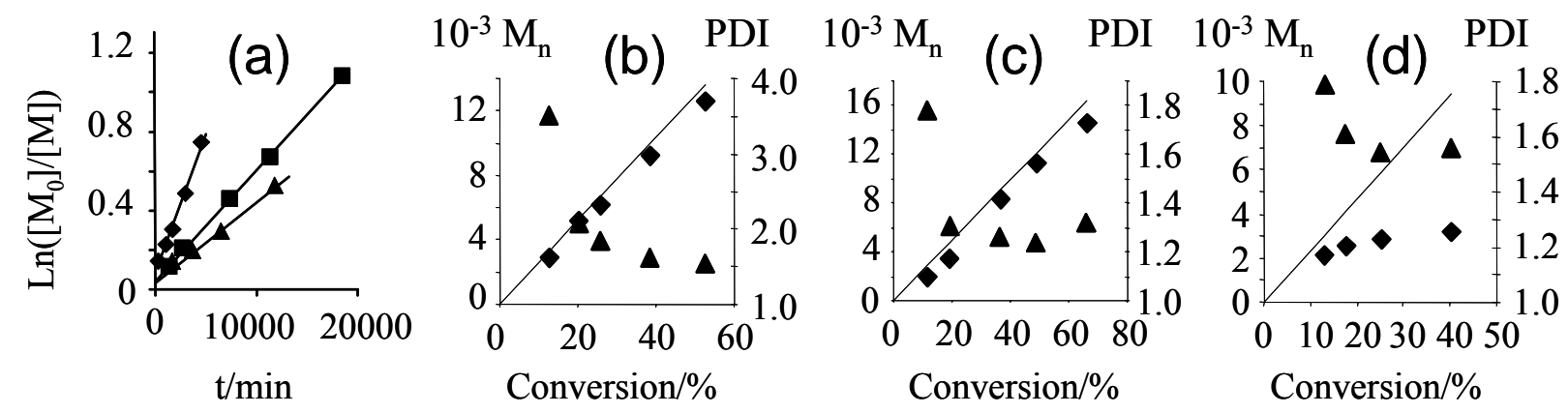

Figure 1. Styrene polymerization in toluene $(30 \% \mathrm{v} / \mathrm{v})$ at $90^{\circ} \mathrm{C}$ in the presence of $\mathrm{MoX}_{3}\left(\mathrm{PMe}_{3}\right)_{3} / \mathrm{BEB}(\mathrm{X}=\mathrm{Cl}, \mathrm{Br}, \mathrm{I})$ : (a) $1^{\text {st }}$ order kinetics (diamonds: $\mathrm{Cl}$; squares: Br; triangles: I); (b)-(d): $\overline{M_{n}}$ (diamonds) and PDI (triangles) as a function of conversion for $\mathrm{X}=\mathrm{Cl}(\mathrm{b}), \mathrm{Br}$ (c) and I (d). The straight lines correspond to the theoretical $\overline{\mathrm{M}_{\mathrm{n}}}$ values. Styrene/Mo ${ }^{\mathrm{III}} / \mathrm{BEB}=251 / 1 / 1$ (b); 244/1/1 (c); 225/1/1 (d).

These results may be discussed on the basis of the previously introduced comprehensive mechanistic scheme, see Scheme 2. ${ }^{[4]}$ The same metal complex $\mathrm{L}_{\mathrm{n}} \mathrm{M}$ (in the present case, any of the $\mathrm{MoX}_{3}\left(\mathrm{PMe}_{3}\right)_{3}$ complexes $)$ may in principle exert three different functions: ATRP catalyst, spin trap for the so-called Stable Free Radical Polymerization (SFRP), and chain transfer catalyst. The ratio between the rate of catalyzed chain transfer $\left(v_{t r}=k_{h}\left[R^{\prime}\right]\left[L_{n} M\right]\right)$ and 
the rate of propagation $\left(\mathrm{v}_{\mathrm{p}}=k_{\mathrm{p}}[\mathrm{R}][\mathrm{m}]\right)$ is shown in Equation $1(\mathrm{~m}=$ monomer). Note in Figure 1 that the experimentally determined $\overline{\mathrm{M}_{\mathrm{n}}}$ are also perceptively smaller than the theoretical values for the $\mathrm{X}=\mathrm{Cl}$ and $\mathrm{Br}$ systems, although these deviations are much less significant than for the $\mathrm{X}=\mathrm{I}$ system. This difference must be due to a greater hydrogen atom transfer rate constant $\left(k_{\mathrm{h}}\right)$ in the presence of the triiodide catalyst, because the other parameters of Equation 1 are identical for the three systems.

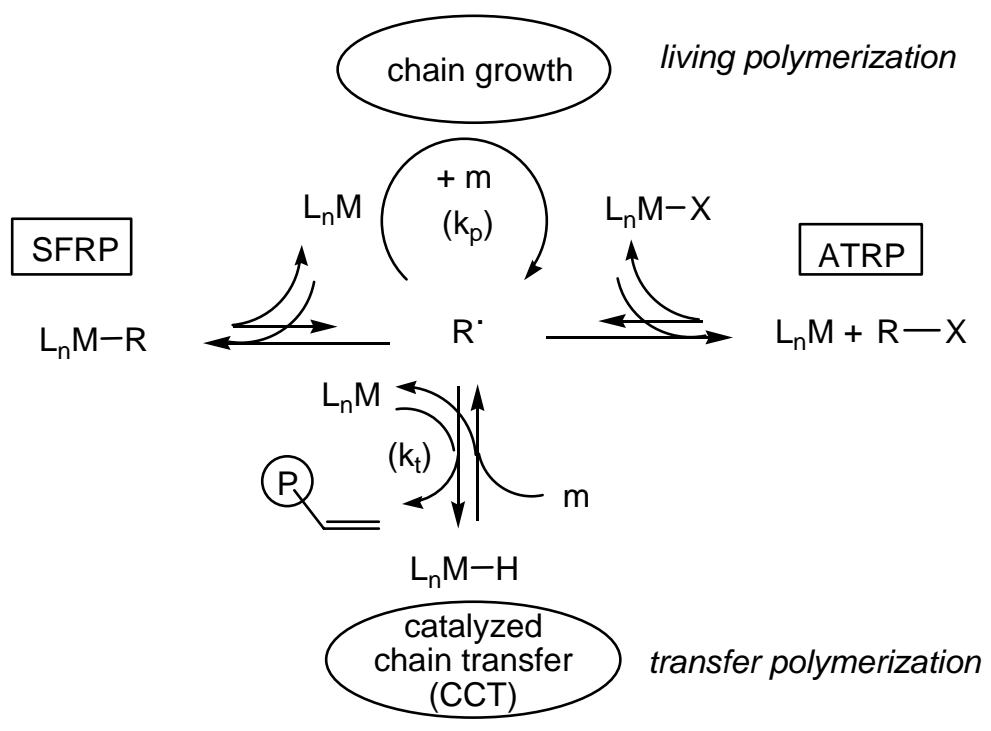

\section{Scheme 2}

\section{Equation 1}

$\frac{\mathrm{v}_{\text {tr }}}{\mathrm{v}_{\mathrm{p}}}=\frac{k_{\mathrm{h}}}{k_{\mathrm{p}}} \frac{\left[\mathrm{L}_{\mathrm{n}} \mathrm{M}\right]}{[\mathrm{m}]}$

A possible reason for this difference can be attributed to a steric control in the competitive $\mathrm{H}$ atom transfer and SFRP trapping reaction. As shown in Scheme 3, the formation of the SFRP dormant species, the organometallic $\mathrm{MoX}(\mathrm{R})\left(\mathrm{PMe}_{3}\right)_{3}$ derivative of $\mathrm{Mo}^{\mathrm{IV}}$, should be more sensitive to the size of the ligands than the hydrogen atom transfer process. Thus, the bulkier triiodide system may constitute a greater obstacle to the formation 
of the dormant $\mathrm{Mo}^{\mathrm{IV}}$ species and consequently more metal complex remains in the form of the $\mathrm{Mo}^{\mathrm{III}}$ chain transfer catalyst. A similar steric influence on competitive chain transfer catalysis and metal-carbon bond formation appears to operate for the $\left(\mathrm{C}_{5} \mathrm{R}_{5}\right) \mathrm{Cr}(\mathrm{CO})_{3}$ system. ${ }^{[18]}$ It is also possible to account for this different behavior on the basis of a greater rate constant for the $\mathrm{H}$ atom transfer process to the triiodide complex, which would necessarily have an electronic origin, though this does not seem obvious to rationalize. We have previously shown that complex $\mathrm{MoCl}_{3}\left(\mathrm{PMe}_{3}\right)_{3}$ is not capable to effectively control the polymerization of styrene under SFRP conditions, i.e. when the polymerization is initiated by thermal decomposition of AIBN. ${ }^{[14]}$ This indicates that the $\mathrm{Mo}^{\mathrm{IV}}-\mathrm{C}$ bond in the $\mathrm{MoCl}_{3}(\mathrm{R})\left(\mathrm{PMe}_{3}\right)_{3}$ complex ( $\mathrm{R}$ = growing polymer chain) is not sufficiently strong to exert a good control of the radical concentration, but does not exclude that a certain amount of the SFRP dormant species may reversibly form under ATRP conditions.

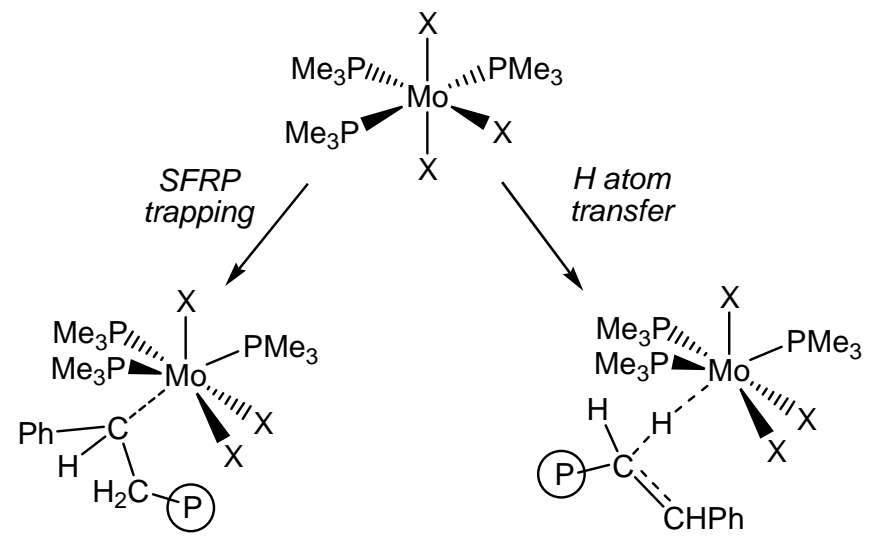

Scheme 3

The apparent polymerization rate constant $\left(k_{\mathrm{app}}\right)$ increases in the order $\mathrm{I}<\mathrm{Br}<\mathrm{Cl}$, as shown in Figure 1(a) and in Table 1. The apparent rate constant for an ATRP process is given by Equation 2, where $K_{\mathrm{AT}}$ is the equilibrium constant of the atom transfer process (i.e. Scheme 1). A detailed comparison of the apparent rate constants is not meaningful, since the values are strongly affected by the equilibrium concentration of the oxidized complex $\left[\mathrm{L}_{\mathrm{n}} \mathrm{M}-\right.$ 
$\mathrm{X}$, which is unknown. A small and uncontrolled amount of the ATRP spin trap, $\mathrm{L}_{n} \mathrm{M}-\mathrm{X}$, usually accumulates at the initial stages of the process because of irreversible bimolecular terminations of the free radicals, before the "persistent radical effect"[19] brings the atom transfer process equilibrium under steady state conditions. Because of different trapping rates, and consequently different extent of bimolecular termination at the initial stages of the polymerization process, $\left[\mathrm{L}_{n} \mathrm{M}-\mathrm{X}\right]$ may be different for the three $\mathrm{Mo}^{\mathrm{III}}$ halide systems. In conclusion, the results of Figure 1 demonstrate that, with all three $\mathrm{Mo}^{\mathrm{III}}$ complexes, BEB is capable of generating free radicals, that the latter are present at approximately constant concentration, and that they are reversibly trapped to yield a dormant species.

$<$ Table 1>

\section{Equation 2}

$$
k_{\text {app }}=k_{\mathrm{p}}\left[\mathrm{R}^{\bullet}\right]=k_{\mathrm{p}} K_{\mathrm{AT}} \frac{\left[\mathrm{L}_{\mathrm{n}} \mathrm{M}\right][\mathrm{R}-\mathrm{X}]}{\left[\mathrm{L}_{\mathrm{n}} \mathrm{M}-\mathrm{X}\right]}
$$

\section{(b) $\mathrm{MoX}_{3}\left(\mathrm{PMe}_{3}\right)_{3}(\mathrm{X}=\mathrm{Cl}$ or I) as radical traps}

In order to test the possibility of radical trapping by complexes $\mathrm{MoX}_{3}\left(\mathrm{PMe}_{3}\right)_{3}$, we have carried out a styrene radical polymerization experiment under SFRP condition (AIBN initiator) in the presence of $\mathrm{MoI}_{3}\left(\mathrm{PMe}_{3}\right)_{3}$ and repeated, for comparison, the same study in the presence of $\mathrm{MoCl}_{3}\left(\mathrm{PMe}_{3}\right)_{3}$ under identical conditions. The results are shown in Figure 2. In either case, the polymerization rates are far from respecting first order kinetics, while the polymerization is slightly faster for the triiodide system, see Figure 2(a). This slight rate difference is a first indication of the fact that the trichloride complex interacts more strongly with the reactive radical than the triiodide complex, thereby slowing down the polymerization rate. However, the interaction is not sufficient to control the chain growth process. The 
evolutions of the $\overline{\mathrm{M}_{\mathrm{n}}}$ and of the PDI are shown in Figure 2(b) for $\mathrm{X}=\mathrm{Cl}$ and in Figure 2(c) for $\mathrm{X}=\mathrm{I}$. For the trichloride system, $\overline{\mathrm{M}_{\mathrm{n}}}$ increases with conversion, but the polydispersity is high, greater than 2. The average mass is about twice that expected on the basis of AIBN, considering a perfect initiator efficiency. For the triiodide system, on the other hand, a polymer with much higher $\overline{\mathrm{M}_{\mathrm{n}}}$ is obtained already at low conversions, followed by little or no further chain growth. This is again indication that compound $\mathrm{MoCl}_{3}\left(\mathrm{PMe}_{3}\right)_{3}$ exerts a weak interaction with the reactive free radicals, whereas the polymerization process occurring in the presence of $\mathrm{MoI}_{3}\left(\mathrm{PMe}_{3}\right)_{3}$ has a closer behavior to that of a classical free radical polymerization.

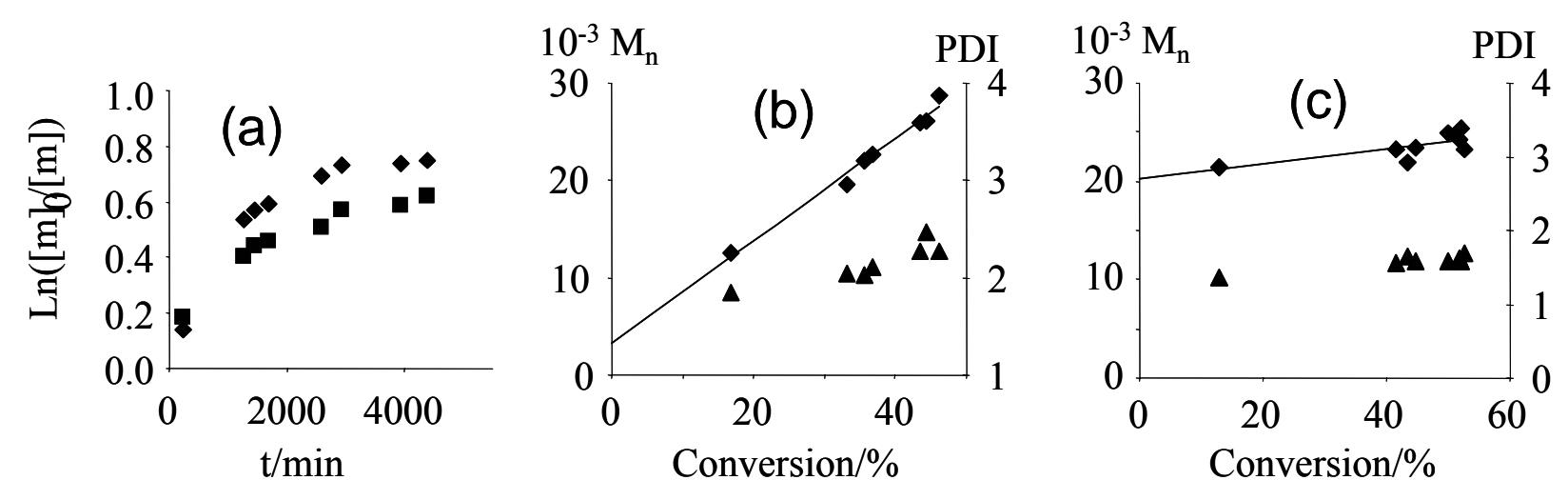

Figure 2. Styrene polymerization in toluene $(30 \% \mathrm{v} / \mathrm{v})$ at $80^{\circ} \mathrm{C}$ in the presence of $\mathrm{MoX}_{3}\left(\mathrm{PMe}_{3}\right)_{3}$ and AIBN. Styrene/Mo ${ }^{\mathrm{III}} / \mathrm{AIBN}=200 / 1 / 0.64(\mathrm{X}=\mathrm{Cl}) ; 250 / 1 / 0.64$ $(\mathrm{X}=\mathrm{I})$ : (a) $1^{\text {st }}$ order kinetics (squares: $\mathrm{Cl}$; diamonds: I); (b)-(c): $\overline{\mathrm{M}_{\mathrm{n}}}$ (diamonds) and PDI (triangles) as a function of conversion for $\mathrm{X}=\mathrm{Cl}(\mathrm{b}), \mathrm{I}(\mathrm{c})$.

The above observations imply that the polystyrene growing radical chains are trapped by both the ATRP and SFRP equilibria when using $\mathrm{MoCl}_{3}\left(\mathrm{PMe}_{3}\right)_{3}$, though the ATRP equilibrium is mostly responsible for keeping the radical concentration at a suitably low level for controlled polymerization. On the other hand, a lower proportion (if any) of the SFRP equilibrium plays a role when using $\mathrm{MoI}_{3}\left(\mathrm{PMe}_{3}\right)_{3}$.

(c) The effect of the $\mathrm{Al}(\mathrm{OiPr})_{3}$ additive 
Given the reported beneficial effect of a Lewis acidic co-catalyst on the polymerization rate and on the molecular weight distribution for ATRP processes carried out with a number of different metal systems, ${ }^{[5,20-23]}$ including half-sandwich complexes of Mo ${ }^{\text {III }}{ }^{[13]}$ we have studied the effect of $\mathrm{Al}(\mathrm{OiPr})_{3}$ on the styrene polymerization controlled by $\mathrm{MoX}_{3}\left(\mathrm{PMe}_{3}\right)_{3}$. The results are summarized in Figure 3. Indeed, the aluminum compound has a significant accelerating effect, as shown in Table 1. The presence of the co-catalyst also improves the degree of control of the polymerization process, as shown by the smaller PDI values. This phenomenon is quite common and is attributed to the acceleration of the activation and deactivation processes. ${ }^{[24]}$

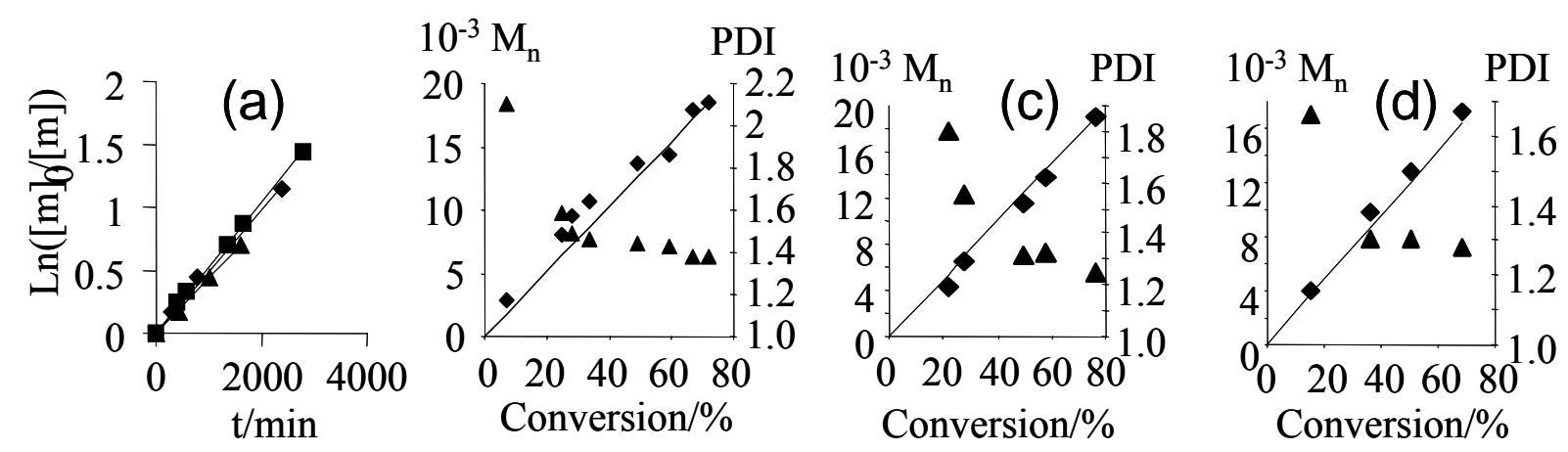

Figure 3. Styrene polymerization in toluene $(30 \% \mathrm{v} / \mathrm{v})$ at $90^{\circ} \mathrm{C}$ in the presence of $\mathrm{MoX}_{3}\left(\mathrm{PMe}_{3}\right)_{3} / \mathrm{BEB} / \mathrm{Al}(\mathrm{OiPr})_{3}(\mathrm{X}=\mathrm{Cl}, \mathrm{Br}, \mathrm{I})$ : (a) $1^{\text {st }}$ order kinetics (diamonds: $\mathrm{Cl}$; squares: Br; triangles: I); (b)-(d): $\overline{\mathrm{M}_{\mathrm{n}}}$ (diamonds) and PDI (triangles) as a function on conversion for $\mathrm{X}=\mathrm{Cl}(\mathrm{a}), \mathrm{Br}(\mathrm{b})$ and $\mathrm{I}(\mathrm{c})$. The straight lines correspond to the theoretical $\overline{\mathrm{M}_{\mathrm{n}}}$ values. Styrene/Mo ${ }^{\mathrm{III}} / \mathrm{BEB} / \mathrm{Al}=246 / 1 / 1 / 1$ (b); 230/1/1/1 (c); $227 / 1 / 1 / 1(d)$.

It is interesting to note that the polymerization catalyzed by $\mathrm{MoI}_{3}\left(\mathrm{PMe}_{3}\right)_{3}$, which gave the highest degree of CCT in the absence of the aluminum compound, becomes pseudo-living in the presence of $\mathrm{Al}(\mathrm{OiPr})_{3}$, as shown by the continuous and linear increase of the $\overline{\mathrm{M}_{\mathrm{n}}}$, in agreement with the theoretical values. This phenomenon may be explained by a selective 
acceleration of the ATRP process by the $\mathrm{Al}(\mathrm{OiPr})_{3}$ co-catalyst, whereas this additive has no effect on the slow step of the CCT process - presumably the hydrogen atom transfer. Thus, the relative importance of CCT is reduced in the presence of the $\mathrm{Al}$ compound. Note that the $\mathrm{MoI}_{3}\left(\mathrm{PMe}_{3}\right)_{3}$ catalyst gives the highest ratio between the apparent polymerization rate constants in the presence and absence of the aluminum additive.

\section{(d) Electrochemistry of $\mathrm{MoX}_{3}\left(\mathrm{PMe}_{3}\right)_{3}$ in the presence of $\mathrm{X}^{-}$}

All three complexes $(\mathrm{X}=\mathrm{Cl}, \mathrm{Br}, \mathrm{I})$ exhibit an oxidation process (see Figure 4), which is electrochemically reversible for $\mathrm{X}=\mathrm{I}\left(\mathrm{E}_{1 / 2}=0.34 \mathrm{~V}\right)$ and only partially reversible for $\mathrm{X}=\mathrm{Br}$ $\left(\mathrm{E}_{1 / 2}=0.29 \mathrm{~V}\right)$ and $\mathrm{Cl}\left(\mathrm{E}_{1 / 2}=0.21 \mathrm{~V}\right)$. The relative height of the return peak decreases on going from the tribromide to the trichloride. In addition, the separation between anodic and cathodic peaks for $\mathrm{X}=\mathrm{Cl}$ and $\mathrm{Br}$ is greater than the theoretical value of $60 \mathrm{mV}$ for a reversible one-electron process, especially for the tribromide complex.

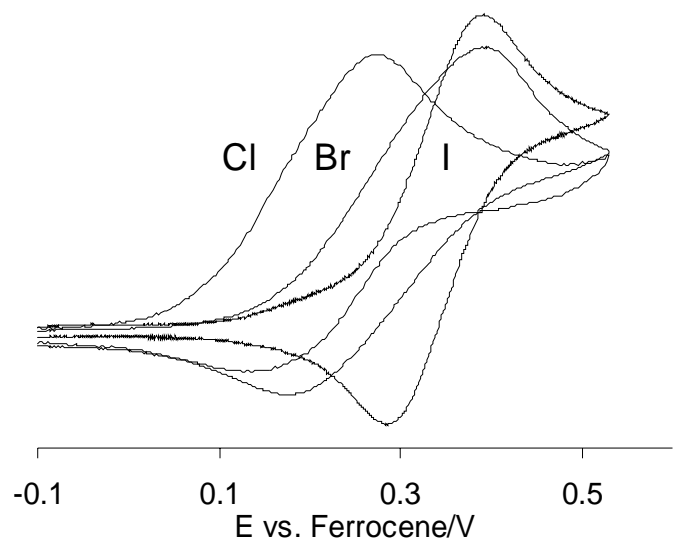

Figure 4. Cyclic voltammetry of complexes $\mathrm{MoX}_{3}\left(\mathrm{PMe}_{3}\right)_{3}(\mathrm{X}=\mathrm{Cl}, \mathrm{Br}, \mathrm{I})$ in $\mathrm{CH}_{2} \mathrm{Cl}_{2}$. Supporting electrolyte $=\mathrm{Bu}_{4} \mathrm{NPF}_{6}$.

It is useful to briefly comment on the relevance of these oxidation potentials to the atom transfer equilibrium. The atom transfer equilibrium may be analyzed in terms of the four 
elementary steps in Scheme $4,{ }^{[25]}$ of which steps (c) and (d) depend on the catalyst nature (the oxidation potential and the "halogenophilicity"). ${ }^{[17]}$ The relative value of the oxidation potential for different $\mathrm{L}_{\mathrm{n}} \mathrm{M}$ complexes gives a qualitative indication of the atom transfer equilibrium position $\left(K_{\mathrm{AT}}\right.$ of Scheme 1$)$, under the assumption that the different complexes possess the same halogenophilicity. If we make this assumption about the affinity of the three oxidized complexes $\left[\mathrm{MoX}_{3}\left(\mathrm{PMe}_{3}\right)_{3}\right]^{+}(\mathrm{X}=\mathrm{Cl}, \mathrm{Br}, \mathrm{I})$ for the bromide ion that originates from the BEB initiator, we may conclude that the triiodide complex should lead to a less extensive atom transfer equilibrium, and consequently to a slower $k_{\text {app }}$, and that the trichloride complex should yield the highest $k_{\text {app. }}$ This indeed corresponds with the experimental observation. Thus, the affinity of the three $\left[\mathrm{MoX}_{3}\left(\mathrm{PMe}_{3}\right)_{3}\right]^{+}$complexes for the $\mathrm{Br}^{-}$ion must be confined within a narrow range.

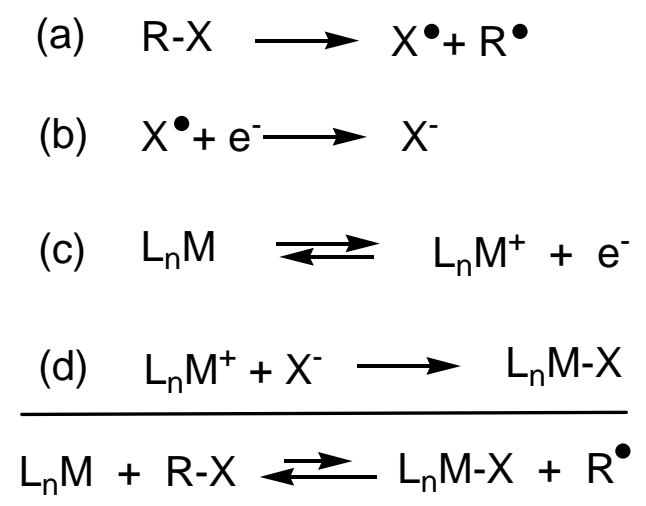

Scheme 4

The addition of halide ions to the solutions causes interesting changes to the voltammetric response. The addition of $\mathrm{Cl}^{-}$to $\mathrm{MoCl}_{3}\left(\mathrm{PMe}_{3}\right)_{3}$ (see Figure 5) or $\mathrm{Br}^{-}$to $\mathrm{MoBr}_{3}\left(\mathrm{PMe}_{3}\right)_{3}$ (see Figure 6) shows the same qualitative changes: (i) the return reduction wave disappears; (ii) the oxidation wave of free $\mathrm{Cl}^{-} / \mathrm{Br}^{-}$[whose potential is more positive than that of $\left.\mathrm{MoX}_{3}\left(\mathrm{PMe}_{3}\right)_{3}\right]$ is not present when using $<1$ equivalent of halide; ${ }^{[26]}$ (iii) the anodic wave of $\mathrm{MoX}_{3}\left(\mathrm{PMe}_{3}\right)_{3}$ shifts slightly to less positive potentials. These combined observations 
are clear evidence that the electrochemical oxidation is followed by a fast chemical process that consumes both $\left[\mathrm{MoX}_{3}\left(\mathrm{PMe}_{3}\right)_{3}\right]^{+}$and $\mathrm{X}^{-}$. This process must obviously be the formation of the neutral $\mathrm{MoX}_{4}\left(\mathrm{PMe}_{3}\right)_{3}$ complex. As stated in the introduction, compound $\mathrm{MoCl}_{4}\left(\mathrm{PMe}_{3}\right)_{3}$ has been reported in the literature ${ }^{[15,27]}$ and the tetrabromide system $\mathrm{MoBr}_{4}\left(\mathrm{PMe}_{2} \mathrm{Ph}\right)_{\mathrm{x}}$ has also been described with both $\mathrm{x}=2$ and $3 .^{[28,29]}$ The proposed formation of the neutral $\mathrm{MoX}_{4}\left(\mathrm{PMe}_{3}\right)_{3}$ complexes was confirmed by the simultaneous appearance of the new reduction waves at ca. $-0.6 \mathrm{~V}$ for $\mathrm{X}=\mathrm{Cl}$ and ca. $-0.1 \mathrm{~V}$ for $\mathrm{X}=\mathrm{Br}$, that can be attributed to these compounds (vide infra).

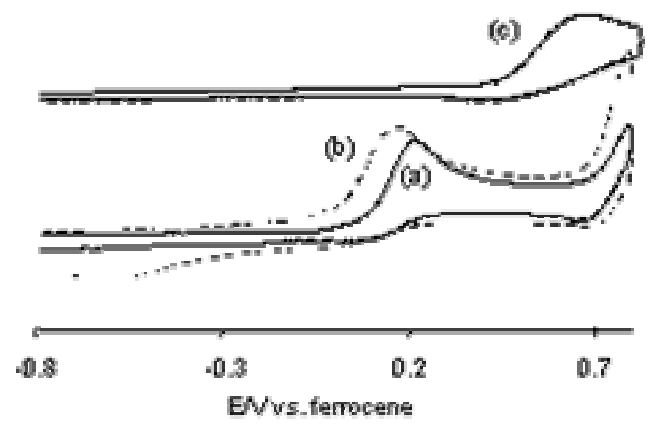

Figure 5. Effect of the addition of $\left[\mathrm{Bu}_{4}^{\mathrm{n}} \mathrm{N}\right][\mathrm{Cl}]$ on the cyclic voltammogram of $\mathrm{MoCl}_{3}\left(\mathrm{PMe}_{3}\right)_{3}$ in $\mathrm{CH}_{2} \mathrm{Cl}_{2}$. (a) Without $\mathrm{Cl}^{-}$; (b) with added $\mathrm{Cl}^{-}$; (c) voltammogram of $\left[\mathrm{Bu}_{4}{ }_{4} \mathrm{~N}\right][\mathrm{Cl}]$.

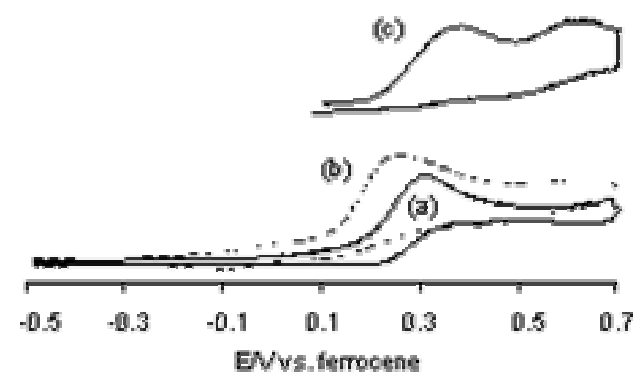

Figure 6. Effect of the addition of $\left[\mathrm{Bu}_{4}^{\mathrm{n}} \mathrm{N}\right][\mathrm{Br}]$ on the cyclic voltammogram of $\mathrm{MoBr}_{3}\left(\mathrm{PMe}_{3}\right)_{3}$ in $\mathrm{CH}_{2} \mathrm{Cl}_{2}$. (a) Without $\mathrm{Br}^{-}$; (b) with added $\mathrm{Br}^{-}$; (c) voltammogram of $\left[\mathrm{Bu}_{4}{ }_{4} \mathrm{~N}\right][\mathrm{Br}]$.

All these changes can be rationalized on the basis of Scheme 5. The one electron oxidation at potential $E_{1}$ is partially reversible because of a decomposition process, which may involve solvent coordination. For $\mathrm{X}=\mathrm{I}$, this must be a slower process (if at all present) leading to a reversible electrochemical process. The presence of free $\mathrm{X}^{-}$opens a new 
decomposition pathway for the oxidation product, with formation of neutral $\mathrm{MoX}_{4}\left(\mathrm{PMe}_{3}\right)_{3}$ for $\mathrm{X}=\mathrm{Cl}$ and $\mathrm{Br}$. The greater halogenophilicity of $\left[\mathrm{MoX}_{3}\left(\mathrm{PMe}_{3}\right)_{3}\right]^{+}$relative to $\mathrm{MoX}_{3}\left(\mathrm{PMe}_{3}\right)_{3}$ $\left(K_{2}>K_{1}\right)$ is thermodynamically related to the easier oxidation of the (unobserved) 17-electron $\left[\mathrm{MoX}_{4}\left(\mathrm{PMe}_{3}\right)_{3}\right]^{-}$complex relative to $\mathrm{MoX}_{3}\left(\mathrm{PMe}_{3}\right)_{3}\left(E_{2}<E_{1}\right)$. They account for the negative shift of the oxidation potential and for the disappearance of the return reduction wave in the presence of $\mathrm{X}^{-}$. A possible alternative reasons for a negative shift of the oxidation potential could be a ligand substitution process to yield the known $\mathrm{MoX}_{4}\left(\mathrm{PMe}_{3}\right)_{2}{ }^{-}$complex. However, this is excluded by a parallel ${ }^{1} \mathrm{H}$ NMR study, which shows no indication for the formation of the anionic product. This indicates that such reaction is thermodynamically unfavorable and/or too slow on the time scale of the cyclic voltammetric experiment. ${ }^{[30,31]}$ The new reduction wave that becomes visible after the addition of $\mathrm{X}^{-}$are processes related to the formation of $\left[\mathrm{MoX}_{4}\left(\mathrm{PMe}_{3}\right)\right]^{+}\left(E_{3}\right.$ for $\mathrm{X}=\mathrm{Br}$ or processes associated to products of further chemical processes for $\mathrm{X}=\mathrm{Cl}$, see section $\mathbf{c})$.

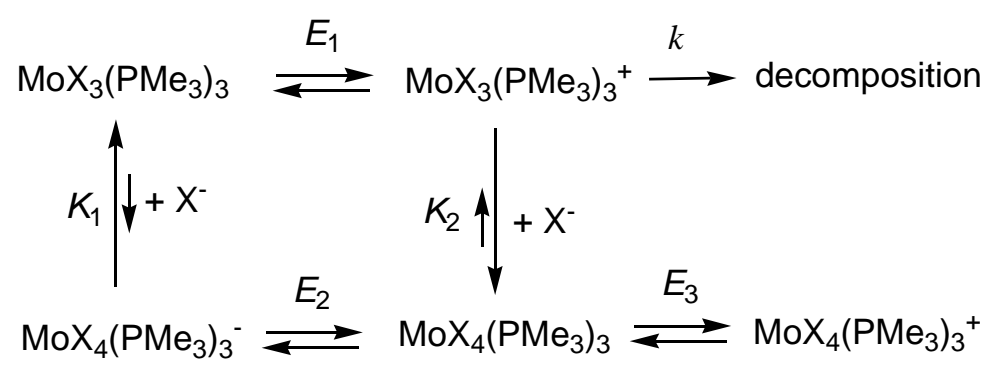

Scheme 5

The addition of $\mathrm{I}^{-}$to $\mathrm{MoI}_{3}\left(\mathrm{PMe}_{3}\right)_{3}$, on the other hand, has no effect on the reversibility nor on the potential of the Mo oxidation process. The oxidation processes of free $\mathrm{I}^{-}$(the first oxidation producing $\mathrm{I}_{3}{ }^{-}$and second one leading to $\mathrm{I}_{2}$ ) are observed even when much less than 1 equivalent is added, and no new band appears, see Figure 7. A key feature is that the two oxidation processes associated to free $\mathrm{I}^{-}$occur at a less positive potential than the oxidation of 
$\mathrm{MoI}_{3}\left(\mathrm{PMe}_{3}\right)_{3}$, suggesting that a hypothetical $\mathrm{MoI}_{4}\left(\mathrm{PMe}_{3}\right)_{3}$ complex would be unstable relative to an internal redox process leading to $\mathrm{MoI}_{3}\left(\mathrm{PMe}_{3}\right)_{3}$ and $\mathrm{I}_{2}$. An estimation based of the anodic peak potentials yields a $0.39 \mathrm{~V}$ difference between the oxidation potential of $\mathrm{MoI}_{3}\left(\mathrm{PMe}_{3}\right)_{3}$ and the thermodynamic oxidation potential relating $\mathrm{I}^{-}$directly with $\mathrm{I}_{2}: E^{\circ}\left(\mathrm{I}^{-} / \mathrm{I}_{2}\right)=\left[2 E^{\circ}\left(\mathrm{I}^{-} / \mathrm{I}_{3}^{-}\right)+\right.$ $\left.\left.E^{\circ}\left(\mathrm{I}_{3}^{-} / \mathrm{I}_{2}\right)\right] / 3\right)$. From this value, we can calculate $\left[\mathrm{I}^{-}\right]^{2} /\left[\mathrm{I}_{2}\right]=1.85 \times 10^{-6}$ at the thermodynamic oxidation potential of $\mathrm{MoI}_{3}\left(\mathrm{PMe}_{3}\right)_{3}$. For a typical concentration of $10^{-2} \mathrm{M}$ for both $\mathrm{MoI}_{3}\left(\mathrm{PMe}_{3}\right)_{3}$ and free $\mathrm{I}^{-}$, this means that only ca. $0.9 \%$ of $\mathrm{I}^{-}$would remain non oxidized at the thermodynamic oxidation potential of the complex. Thus, the equilibrium constant for the iodide addition to $\left[\mathrm{MoI}_{3}\left(\mathrm{PMe}_{3}\right)_{3}\right]^{+}$(halogenophilicity, i.e. $K_{2}$ in Scheme 5), would need to be very high to guarantee the stability of $\mathrm{MoI}_{4}\left(\mathrm{PMe}_{3}\right)_{3}$ with respect to the internal redox decomposition, see Scheme 6. It is relevant to mention here that $\mathrm{MoI}_{4}$ is not a known compound ${ }^{[32]}$ and, although additional ligands stabilize higher oxidation state $\mathrm{MoI}_{4}$ moieties (e.g. in compounds $\left[\mathrm{CpMoI}_{4}\right]^{-}$and $\left.\left[\mathrm{MoOI}_{4}\right]^{-}\right),{ }^{[33,34]}$ no $\mathrm{MoI}_{4} \mathrm{~L}_{\mathrm{n}}$ or iodide-containing mixedhalide $\mathrm{MoI}_{\mathrm{n}} \mathrm{X}_{4-\mathrm{n}} \mathrm{L}_{\mathrm{m}}$ coordination compounds where $\mathrm{L}=$ phosphine ligand are reported in the literature to the best of our knowledge.

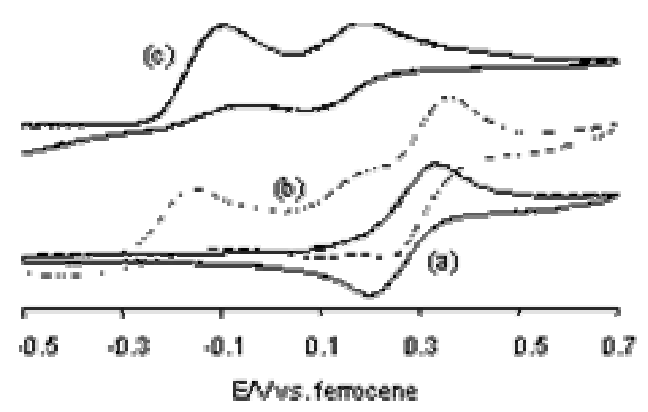

Figure 7. Effect of the addition of $\left[\mathrm{Pr}_{4}^{\mathrm{n}} \mathrm{N}\right][\mathrm{I}]$ on the cyclic voltammogram of $\mathrm{MoI}_{3}\left(\mathrm{PMe}_{3}\right)_{3}$ in $\mathrm{CH}_{2} \mathrm{Cl}_{2}$. (a) Without $\mathrm{I}^{-}$; (b) with added $\mathrm{I}^{-}$; (c) voltammogram of $\left[\operatorname{Pr}^{\mathrm{n}}{ }_{4} \mathrm{~N}\right][\mathrm{I}]$. 


$$
\begin{aligned}
& {\left[\mathrm{MoI}_{3}\left(\mathrm{PMe}_{3}\right)_{3}\right]^{+}+\mathrm{I}^{-} \rightleftharpoons \mathrm{MoI}_{4}\left(\mathrm{PMe}_{3}\right)_{3} \quad K_{2}} \\
& \left.\begin{array}{l}
\left.\mathrm{MoI}_{3}\left(\mathrm{PMe}_{3}\right)_{3} \rightleftharpoons \mathrm{MoI}_{3}\left(\mathrm{PMe}_{3}\right)_{3}\right]^{+}+\mathrm{e}^{-} \\
1 / 2 \mathrm{I}_{2}+\mathrm{e}^{-} \rightleftharpoons \mathrm{I}^{-}
\end{array}\right\} \begin{array}{c}
K_{\text {redox }}=\exp (-0.39 / 0.0591)= \\
1.4 \times 10^{-3}
\end{array} \\
& \mathrm{MoI}_{3}\left(\mathrm{PMe}_{3}\right)_{3}+1 / \mathrm{I}_{2} \rightleftharpoons \mathrm{MoI}_{4}\left(\mathrm{PMe}_{3}\right)_{3} \quad K=1.4 \times 10^{-3} K_{2}
\end{aligned}
$$

\section{Scheme 6}

\section{(e) Electrochemistry of $\mathrm{MoX}_{3}\left(\mathrm{PMe}_{3}\right)_{3}$ in the presence of $\mathrm{Y}^{-} \neq \mathrm{X}^{-}$}

We have also carried out electrochemical experiments with mixed halide systems, i.e. adding $\mathrm{Y}^{-}$to a solution of $\mathrm{MoX}_{3}\left(\mathrm{PMe}_{3}\right)_{3}$ where $\mathrm{Y} \neq \mathrm{X}$. These experiments have provided useful complementary information. The addition of $\mathrm{Br}^{-}(<1$ equiv) to a solution of $\mathrm{MoCl}_{3}\left(\mathrm{PMe}_{3}\right)_{3}$, and the addition of $\mathrm{Cl}^{-}\left(<1\right.$ equiv) to a solution of $\mathrm{MoBr}_{3}\left(\mathrm{PMe}_{3}\right)_{3}$, caused the same voltammetric changes as the related experiments on the $\mathrm{MoX}_{3}\left(\mathrm{PMe}_{3}\right)_{3} / \mathrm{X}^{-}$solutions $(\mathrm{X}=$ $\mathrm{Cl}, \mathrm{Br})$, e.g. see the results of the $\mathrm{MoBr}_{3}\left(\mathrm{PMe}_{3}\right)_{3} / \mathrm{Cl}^{-}$experiment in Figure 8: suppression of the return wave for the reduction of $\left[\mathrm{MoX}_{3}\left(\mathrm{PMe}_{3}\right)_{3}\right]^{+}$, slight shift of the anodic peak potential to less positive values, and no wave associated to the oxidation of free $\mathrm{X}^{-}$. A new reduction wave with very small intensity developed at ca. $-0.19 \mathrm{~V}$ for the $\mathrm{MoCl}_{3}\left(\mathrm{PMe}_{3}\right)_{3} / \mathrm{Br}^{-}$ experiment, whereas no new reduction process was clearly visible in the $\mathrm{MoBr}_{3}\left(\mathrm{PMe}_{3}\right)_{3} / \mathrm{Cl}^{-}$ experiment. In light of the above discussion, these observations indicate that the addition of $\mathrm{Br}^{-}$to $\left[\mathrm{MoCl}_{3}\left(\mathrm{PMe}_{3}\right)_{3}\right]^{+}$has occurred to yield a neutral $\mathrm{MoBrCl}_{3}\left(\mathrm{PMe}_{3}\right)_{3}$ complex.

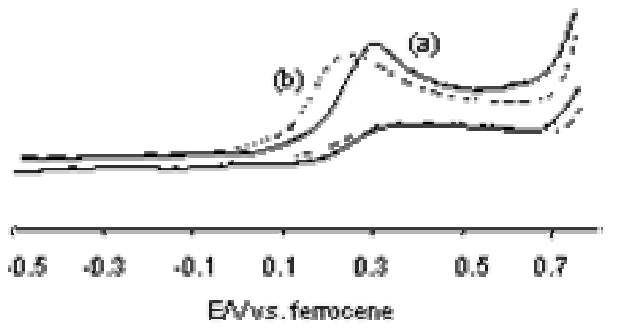

Figure 8. Effect of the addition of $\left[\mathrm{Bu}^{\mathrm{n}}{ }_{4} \mathrm{~N}\right][\mathrm{Cl}]$ on the cyclic voltammogram of $\mathrm{MoBr}_{3}\left(\mathrm{PMe}_{3}\right)_{3}$ in $\mathrm{CH}_{2} \mathrm{Cl}_{2}$. (a) Without $\mathrm{Cl}^{-}$; (b) with added $\mathrm{Cl}^{-}$. 
The addition of $\mathrm{I}^{-}$to the same solutions causes different changes, see Figure 9 for the $\mathrm{MoCl}_{3}\left(\mathrm{PMe}_{3}\right)_{3} / \mathrm{I}^{-}$experiment and Figure 10 for the $\mathrm{MoBr}_{3}\left(\mathrm{PMe}_{3}\right)_{3} / \mathrm{I}^{-}$experiment. Since the oxidation potential of $\mathrm{I}^{-}$is less positive than those of the $\mathrm{Mo}^{\mathrm{III}}$ complexes, this ion is oxidized first to form the $\mathrm{I}_{3}{ }^{-}$ion. Subsequently, the behavior depends on the nature of the halide ligands in the Mo ${ }^{\mathrm{III}}$ complex. The oxidation of the Mo trichloride complex occurs approximately at the same potential as the oxidation of free $\mathrm{I}_{3}{ }^{-}$to $\mathrm{I}_{2}$. The affinity by the oxidized $\mathrm{Mo}^{\mathrm{IV}}$ complex for coordination of the $\mathrm{I}_{3}^{-}$ion results in a slightly shift of the oxidation peak of the metal complex towards less positive potentials, and in a strong shift of the oxidation peak of the coordinated $\mathrm{I}_{3}{ }^{-}$toward more positive potentials (ca. $0.52 \mathrm{~V}$ ). The relative magnitude of these potential shifts reflects the larger electron density change experienced by the $\mathrm{I}_{3}^{-}$ligand, relative to the $\mathrm{Mo}^{\mathrm{IV}}$ metal center, upon coordination. The intensity of the oxidation wave at ca. $0.52 \mathrm{~V}$ is proportional to that of the $\mathrm{I}^{-}$oxidation: increasing the amount of $\mathrm{I}^{-}$salt increases the intensity of both waves relative to that of the Mo complex, which in turn continues to shift negatively. The proposed formation of a $\mathrm{MoCl}_{3}\left(\mathrm{I}_{3}\right)\left(\mathrm{PMe}_{3}\right)_{3}$ complex of $\mathrm{Mo}^{\mathrm{IV}}$ is also consistent with the decrease of the return reduction wave. Mo complexes containing $\mathrm{I}_{3}^{-}$as a ligand have been isolated and structurally characterized, e.g. the anion of compound $\left[\left(\eta^{6}-\mathrm{C}_{6} \mathrm{Me}_{6}\right) \mathrm{MoI}(\mathrm{CO})_{3}\right]\left[\mathrm{MoI}_{2}\left(\mathrm{I}_{3}\right)(\mathrm{CO})_{4}\right] .{ }^{[35]}$ The oxidation process at $0.52 \mathrm{~V}$ must be the mere oxidation of coordinated $\mathrm{I}_{3}{ }^{-}$to free $\mathrm{I}_{2}$, with release of a $\mathrm{Mo}^{\mathrm{IV}}$ complex, and not a metal-centered oxidation, since an oxidation process in this region is absent from the other voltammograms discussed above.

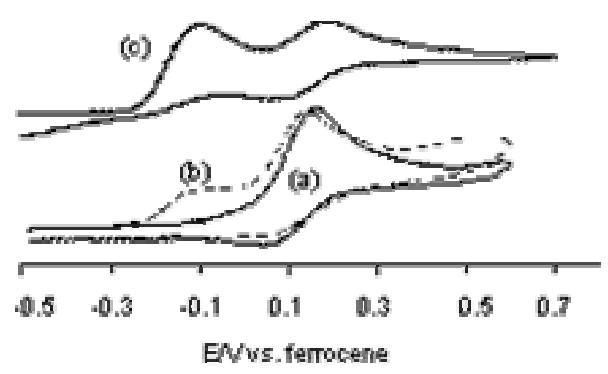


Figure 9. Effect of the addition of $\left[\operatorname{Pr}_{4}^{\mathrm{n}} \mathrm{N}\right][\mathrm{I}]$ on the cyclic voltammogram of $\mathrm{MoCl}_{3}\left(\mathrm{PMe}_{3}\right)_{3}$ in $\mathrm{CH}_{2} \mathrm{Cl}_{2}$. (a) Without $\mathrm{I}^{-}$; (b) with added $\mathrm{I}^{-}$; (c) voltammogram of $\left[\operatorname{Pr}^{\mathrm{n}}{ }_{4} \mathrm{~N}\right][\mathrm{I}]$.

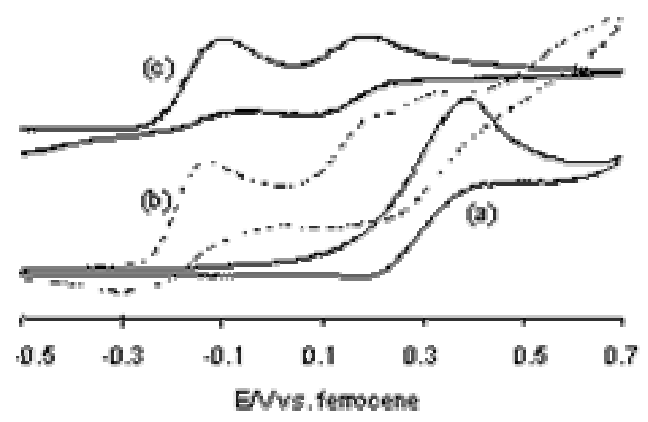

Figure 10. Effect of the addition of $\left[\operatorname{Pr}_{4}^{\mathrm{n}}{ }_{4} \mathrm{~N}\right][\mathrm{I}]$ on the cyclic voltammogram of $\mathrm{MoBr}_{3}\left(\mathrm{PMe}_{3}\right)_{3}$ in $\mathrm{CH}_{2} \mathrm{Cl}_{2}$. (a) Without $\mathrm{I}^{-}$; (b) with added $\mathrm{I}^{-}$; (c) voltammogram of $\left[\operatorname{Pr}_{4}^{\mathrm{n}} \mathrm{N}\right][\mathrm{I}]$.

For the $\mathrm{MoBr}_{3}\left(\mathrm{PMe}_{3}\right)_{3}$ complex, the oxidation process occurs at a more positive potential than the oxidation of $\mathrm{I}_{3}{ }^{-}$, thus the latter occurs first, see voltammogram (b) in Figure 10. However, a slight negative shift of the metal oxidation wave and the appearance of a second oxidation wave (ca. $0.6 \mathrm{~V}$ ) are again observed. We presume that this occurs because the difference between the oxidation potentials of $\mathrm{I}_{3}{ }^{-}$and $\mathrm{MoBr}_{3}\left(\mathrm{PMe}_{3}\right)_{3}$ is small, leaving a significant equilibrium amount of $\mathrm{I}_{3}{ }^{-}$at the potential at which the $\mathrm{Mo}^{\mathrm{IV}}$ complex forms. Note that a similar phenomenon is not observed for the $\mathrm{MoI}_{3}\left(\mathrm{PMe}_{3}\right)_{3} / \mathrm{I}^{-}$experiment (Figure 7), presumably the result of a greater potential difference between the $\mathrm{I}_{3}{ }^{-}$and $\mathrm{MoI}_{3}\left(\mathrm{PMe}_{3}\right)_{3}$ oxidations, or a smaller affinity of $\left[\mathrm{MoI}_{3}\left(\mathrm{PMe}_{3}\right)_{3}\right]^{+}$for $\mathrm{I}_{3}^{-}$, or a combination of both effects.

Finally, the cyclic voltammetric study of the $\mathrm{MoI}_{3}\left(\mathrm{PMe}_{3}\right)_{3}$ solution in the presence of $\mathrm{Cl}^{-}$or $\mathrm{Br}^{-}$(Figure 11) reveals an additional phenomenon, namely halide exchange. The voltammograms clearly show the two characteristic oxidation waves associated to free $\mathrm{I}^{-}$and, in the first case, the consumption of the $\mathrm{Cl}^{-}$ion. In the second case, the consumption of $\mathrm{Br}^{-}$ cannot be clearly established because the oxidation wave of free $\mathrm{Br}^{-}$occurs at essentially the same potential as that of the Mo complex. It must be noted that the added $\mathrm{X}^{-}(\mathrm{X}=\mathrm{Cl}$ or $\mathrm{Br})$ may be consumed not only by the halide exchange process, but also by addition to the product 
of oxidization following halide exchange, $\left[\mathrm{MoX}_{\mathrm{x}} \mathrm{I}_{3-\mathrm{x}}\left(\mathrm{PMe}_{3}\right)_{3}\right]^{+}$. The results of these two last electrochemical studies suggest a preference of this $\mathrm{Mo}^{\mathrm{III}}$ system for the harder halide anion, with release of the softer one $\left(\mathrm{I}^{-}\right)$in solution. Along this line, we would also predict the release of $\mathrm{Br}^{-}$from the $\mathrm{MoBr}_{3}\left(\mathrm{PMe}_{3}\right)_{3} / \mathrm{Cl}^{-}$experiment (Figure 8), but a wave corresponding to free $\mathrm{Br}^{-}$is not seen. However, any $\mathrm{Br}^{-}$generated by the exchange process would be trapped by the oxidized $\left[\mathrm{MoCl}_{\mathrm{X}} \mathrm{Br}_{3-\mathrm{x}}\left(\mathrm{PMe}_{3}\right)_{3}\right]^{+}(\mathrm{X}=\mathrm{Cl}, \mathrm{Br})$ complex (by extension of the behavior discussed above in relation to Figure 5 and Figure 6). Therefore, the lack of observation of free $\mathrm{Br}^{-}$in Figure 8 is expected. Because of this phenomenon, the occurrence of halide exchange in the $\mathrm{MoBr}_{3}\left(\mathrm{PMe}_{3}\right)_{3} / \mathrm{Cl}^{-}$experiment cannot be clearly established by the electrochemical experiment. For the same reason, a halide exchange in the opposite direction cannot be established is the $\mathrm{MoCl}_{3}\left(\mathrm{PMe}_{3}\right)_{3} / \mathrm{Br}^{-}$experiment. It is only by virtue of the less positive oxidation potential of the iodide ion relative to the three $\mathrm{Mo}^{\mathrm{III}}$ complexes that allows the establishment of its formation from $\mathrm{MoI}_{3}\left(\mathrm{PMe}_{3}\right)_{3}$ and $\mathrm{Cl}^{-}$or $\mathrm{Br}^{-}$and the absence of a major consumption upon its interaction with $\mathrm{MoX}_{3}\left(\mathrm{PMe}_{3}\right)_{3}(\mathrm{X}=\mathrm{Cl}, \mathrm{Br})$. As an important corollary, this halide exchange phenomenon suggests that neutral iodide-substituted $\mathrm{Mo}^{\text {IV }}$ complexes such as $\mathrm{MoI}_{3} \mathrm{X}\left(\mathrm{PMe}_{3}\right)_{3}(\mathrm{X}=\mathrm{Cl}, \mathrm{Br})$, obtained by $\mathrm{X}$ atom transfer to $\mathrm{MoI}_{3}\left(\mathrm{PMe}_{3}\right)_{3}$, may also be unstable species relative to iodide dissociation leading to a redox process, with formation of $\mathrm{I}_{2}$ and a $\mathrm{Mo}(\mathrm{III})$ product.

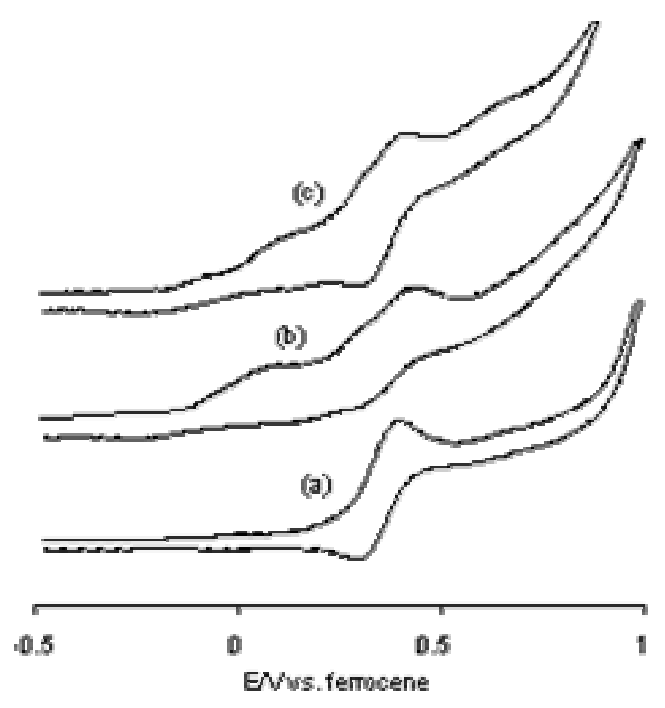


Figure 11. Effect of the addition of $\left[\mathrm{Bu}^{\mathrm{n}}{ }_{4} \mathrm{~N}\right][\mathrm{Cl}]$ and $\left[\mathrm{Bu}_{4}{ }_{4} \mathrm{~N}\right][\mathrm{Br}]$ on the cyclic voltammogram of $\mathrm{MoI}_{3}\left(\mathrm{PMe}_{3}\right)_{3}$ in $\mathrm{CH}_{2} \mathrm{Cl}_{2}$. (a) Without added salts; (b) with added $\mathrm{Cl}^{-}$; (c) with added $\mathrm{Br}^{-}$.

In conclusion, the electrochemical experiments suggest that the $\mathrm{MoX}_{4}\left(\mathrm{PMe}_{3}\right)_{3}$ complexes are thermodynamically stable as neutral species for $\mathrm{X}=\mathrm{Cl}$ and $\mathrm{Br}$, whereas a question remains about the thermodynamic stability of $\mathrm{MoI}_{3} \mathrm{X}\left(\mathrm{PMe}_{3}\right)_{3}(\mathrm{X}=\mathrm{Cl}, \mathrm{Br}, \mathrm{I})$ species with respect to $\mathrm{MoI}_{2} \mathrm{X}\left(\mathrm{PMe}_{3}\right)_{3}$ and $1 / 2 \mathrm{I}_{2}$. As mentioned above, phosphine substituted coordination compounds of $\mathrm{MoI}_{4}$ are not present in the literature. According to our cyclic voltammetric results, the $\left[\mathrm{MoI}_{3}\left(\mathrm{PMe}_{3}\right)_{3}\right]^{+}$cation is the only species encountered in this study which is electrochemically stable while containing iodide ligands on Mo(IV). The addition of any $\mathrm{X}^{-}$ligand to this species triggers an internal redox process resulting in metal reduction and I' $^{-}$oxidation. In order to verify these electrochemical results, synthetic oxidation studies were carried out as detailed in the next section.

\section{(f) Dihalogen oxidations of $\mathrm{MoX}_{3}\left(\mathrm{PMe}_{3}\right)_{3}$.}

The oxidations of $\mathrm{MoX}_{3}\left(\mathrm{PMe}_{3}\right)_{3}(\mathrm{X}=\mathrm{Cl}, \mathrm{Br})$ with $\mathrm{Br}_{2}$ were carried out at $0^{\circ} \mathrm{C}$ in toluene. They lead to an immediate color change to red $\left(\mathrm{MoCl}_{3} \mathrm{Br}\left(\mathrm{PMe}_{3}\right)_{3}\right)$ or dark green $\left(\mathrm{MoBr}_{4}\left(\mathrm{PMe}_{3}\right)_{3}\right)$ and to the precipitation of the sparingly soluble products, see Equation 3, which could be recovered in analytically pure form. The compounds are paramagnetic but show relatively sharp ${ }^{1} \mathrm{H}$ NMR resonances in $\mathrm{C}_{6} \mathrm{D}_{6}$, which are paramagnetically shifted to $\delta$ $17.0\left(\mathrm{w}_{1 / 2}=150 \mathrm{~Hz}\right)$ for $\mathrm{MoCl}_{3} \mathrm{Br}\left(\mathrm{PMe}_{3}\right)_{2}$ and $-17.6\left(\mathrm{w}_{1 / 2}=90 \mathrm{~Hz}\right)$ for $\mathrm{MoBr}_{4}\left(\mathrm{PMe}_{3}\right)_{3}$ at room temperature. These shifts are very similar to that reported for the tetrachloride analogue $(\delta$ 17, $\mathrm{w}_{1 / 2}=130 \mathrm{~Hz}$ at room temperature in $\left.\mathrm{CDCl}_{3}\right) .{ }^{[27]} \mathrm{A}$ new measurement of the $\mathrm{MoCl}_{4}\left(\mathrm{PMe}_{3}\right)_{3}$ spectrum in $\mathrm{C}_{6} \mathrm{D}_{6}$ gives a resonance at $\delta-17.3$ with $\mathrm{w}_{1 / 2}=145 \mathrm{~Hz}$. Notably, 
compound $\mathrm{MoBr}_{4}\left(\mathrm{PMe}_{3}\right)_{3}$ shows no tendency to dissociate a phosphine ligand (no ${ }^{1} \mathrm{H}$ or ${ }^{31} \mathrm{P}$ NMR resonance is observed for free $\mathrm{PMe}_{3}$ ).

\section{Equation 3}

$\begin{aligned} \mathrm{MoX}_{3}\left(\mathrm{PMe}_{3}\right)_{3}+1 / 2 \mathrm{Br}_{2} \longrightarrow & \mathrm{MoX}_{3} \mathrm{Br}\left(\mathrm{PMe}_{3}\right)_{3} \\ & (\mathrm{X}=\mathrm{Cl}, \mathrm{Br})\end{aligned}$

The molecular nature of these new $\mathrm{Mo}^{\mathrm{IV}}$ complexes was established by single crystal Xray analyses. For both species, the coordination geometry (see Supporting Information) is identical to that of $\mathrm{MoCl}_{4}\left(\mathrm{PMe}_{2} \mathrm{Ph}\right)_{3}{ }^{[16]}$ and $\mathrm{MoBr}_{4}\left(\mathrm{PMe}_{2} \mathrm{Ph}\right)_{3}{ }^{[29]}$ It can be described as a capped octahedron where the triangular face defined by the three $\mathrm{P}$ atoms is capped by a halogen atom. The structure of the mixed-halide $\mathrm{MoCl}_{3} \mathrm{Br}\left(\mathrm{PMe}_{3}\right)_{3}$ complex shows positional disorder, with the $\mathrm{Br}$ atom distributed over the three trigonal halide coordination positions but no occupancy was found in the unique axial position. This localized disorder suggests stereochemical selectivity for the bromine addition reaction, with attack at a triangular face defined by one $\mathrm{P}$ and two $\mathrm{Cl}$ atoms as shown in Scheme 7, as well as the absence of a facile pathway for intramolecular exchange between the axial and trigonal halide ligands. Note that the reaction is mechanistically related to the atom transfer step that produces the reactive organic radical. Thus, the latter process may also occur stereoselectively to yield a $\mathrm{Mo}^{\mathrm{IV}}$ complex where the transferred atom occupies a trigonal position. Mechanistically, it is also possible that $\mathrm{Br}_{2}$ adds to the 15-electron $\mathrm{Mo}^{\mathrm{III}}$ complex to produce 17-electron $\mathrm{MoCl}_{3}\left(\mathrm{PMe}_{3}\right)_{3}\left(\mathrm{Br}_{2}\right)$, which then delivers $\mathrm{a} \mathrm{Br}$ atom to a second molecule of the Mo complex. 


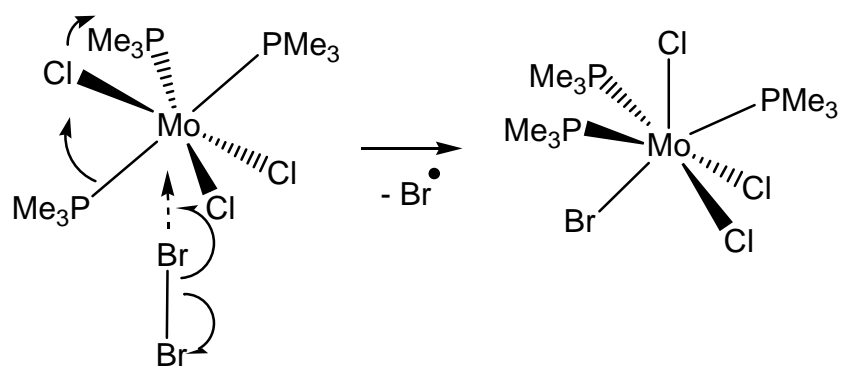

\section{Scheme 7}

Compounds $\mathrm{MoX}_{4}\left(\mathrm{PMe}_{3}\right)_{3}$ have also been studied by cyclic voltammetry, in order to confirm the nature of the chemical species produced during the cyclic voltammetric analyses of the $\mathrm{MoX}_{3}\left(\mathrm{PMe}_{3}\right)_{3} / \mathrm{X}^{-}$solutions (see previous section). Both compounds show a first oxidation wave (reversible for the tetrabromo species, quasi-reversible for the tetrachloro species) with $\mathrm{E}_{1 / 2}=-0.15 \mathrm{~V}(\mathrm{X}=\mathrm{Cl})$ and $-0.06 \mathrm{~V}(\mathrm{X}=\mathrm{Br})$, see Figure 12. The $\Delta \mathrm{E}_{\mathrm{p}}$ for each process $(\mathrm{Cl}, 75 \mathrm{mV} ; \mathrm{Br}, 72 \mathrm{mV})$ is in agreement with a one-electron process, generating the $\mathrm{Mo}^{\mathrm{V}}$ complex $\left[\mathrm{MoX}_{4}\left(\mathrm{PMe}_{3}\right)_{3}\right]^{+}$as the primary oxidation product. The tetrachloro cation is more reactive than the tetrabromo analogue, probably evolving by coordination of Lewis bases available in the medium. Each process is followed by a second, irreversible oxidation, not shown in Figure 12, whose intensity corresponds to that of the first oxidation, probably yielding a very reactive $\mathrm{Mo}^{\mathrm{VI}}$ dicationic complex. The reduction peak associated to the oxidation process of $\mathrm{MoBr}_{4}\left(\mathrm{PMe}_{3}\right)_{3}$ occurs at the same potential of the new peak that develops in the cyclic voltammetric study of $\mathrm{MoBr}_{3}\left(\mathrm{PMe}_{3}\right)_{3}$ in the presence of $\mathrm{Br}^{-}$(Figure 6). This confirms that the one-electron oxidation product generated from $\mathrm{MoBr}_{3}\left(\mathrm{PMe}_{3}\right)_{3}$ binds a bromide ion to form $\mathrm{MoBr}_{4}\left(\mathrm{PMe}_{3}\right)_{3}$. On the other hand, the reduction wave associated to the oxidation process of $\mathrm{MoCl}_{4}\left(\mathrm{PMe}_{3}\right)_{3}$ is not observed in the cyclic voltammetric study of $\mathrm{MoCl}_{3}\left(\mathrm{PMe}_{3}\right)_{3}$ in the presence of $\mathrm{Cl}^{-}$(Figure 5). Instead, a broad feature appeared at ca. -0.6 V. This phenomenon can be explained by the higher reactivity of $\left[\mathrm{MoCl}_{4}\left(\mathrm{PMe}_{3}\right)_{3}\right]^{+}$. Indeed, the addition of excess $\mathrm{Bu}_{4} \mathrm{~N}^{+} \mathrm{Cl}^{-}$to the $\mathrm{MoCl}_{4}\left(\mathrm{PMe}_{3}\right)_{3}$ solution results in the complete 
disappearance of the reduction peak at ca. $-0.19 \mathrm{~V}$ and the appearance of a broad reduction feature at more negative potentials. This phenomenon has not been investigated further. For our purposes, we may conclude that this behavior is consistent with the formation of $\mathrm{MoCl}_{4}\left(\mathrm{PMe}_{3}\right)_{3}$ after oxidation of $\mathrm{MoCl}_{3}\left(\mathrm{PMe}_{3}\right)_{3}$ in the presence of $\mathrm{Cl}^{-}$(Scheme 5).

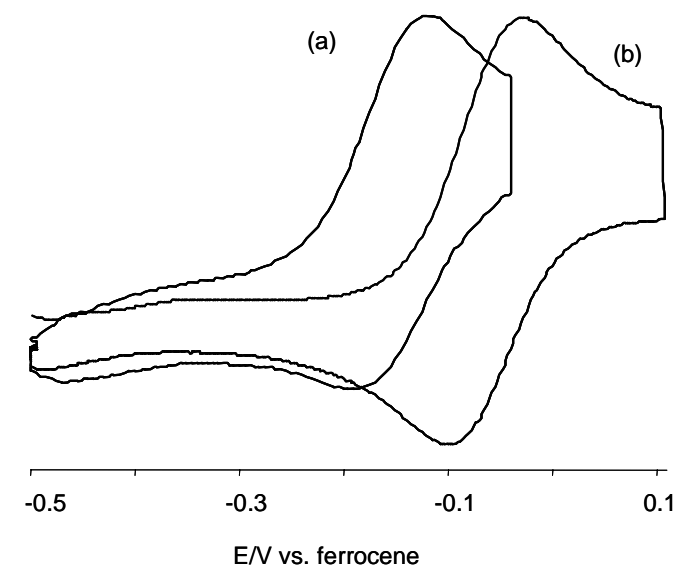

Figure 12. Cyclic voltammogram of $\mathrm{MoX}_{4}\left(\mathrm{PMe}_{3}\right)_{3}$ in $\mathrm{CH}_{2} \mathrm{Cl}_{2}$. (a) $\mathrm{X}=\mathrm{Cl}$. (b) $\mathrm{X}=\mathrm{Br}$.

The oxidations of $\mathrm{MoI}_{3}\left(\mathrm{PMe}_{3}\right)_{3}$ with $\mathrm{Br}_{2}$ or $\mathrm{I}_{2}$, carried out under the same conditions as the oxidation of the lighter trihalide analogues, produced very different results. Rapid precipitation of a yellow-green ( $\mathrm{I}_{2}$ oxidation) or apple green $\left(\mathrm{Br}_{2}\right.$ oxidation) occurred. These products are too insoluble in aromatic hydrocarbons to record a ${ }^{1} \mathrm{H}$ NMR spectrum in $\mathrm{C}_{6} \mathrm{D}_{6}$, thus possess very different solubility properties relative to the above described $\mathrm{MoX}{ }_{3} \mathrm{Br}\left(\mathrm{PMe}_{3}\right)_{3}$ products with $\mathrm{X}=\mathrm{Cl}$, Br. They are soluble in polar solvents such as acetone and nitromethane and show a ${ }^{1} \mathrm{H}$ NMR resonance in a completely different region relative to $\mathrm{MoX}_{3} \mathrm{Y}\left(\mathrm{PMe}_{3}\right)_{3}$ where $\mathrm{X}_{3} \mathrm{Y}=\mathrm{Cl}_{4}, \mathrm{Cl}_{3} \mathrm{Br}$, and $\mathrm{Br}_{4}$. Finally, the compounds are obtained in $<$ $50 \%$ yields when using one half equivalent of the dihalogen oxidant (as required by the stoichiometry of Equation 3). This reflects the consumption of a greater amount of dihalogen. The identity of the products of these reactions as iodophosphosnium salts, see Equation 4, was confirmed by an X-ray determination of the product of the diiodine 
oxidation. The $\left[\mathrm{MoI}_{4}\left(\mathrm{PMe}_{3}\right)_{2}\right]^{-}$complex was previously isolated as a $\mathrm{PPh}_{4}{ }^{+} \mathrm{salt}^{[36]}$ and reported as showing a ${ }^{1} \mathrm{H}$ NMR resonance $\delta-41.2\left(\mathrm{w}_{1 / 2}=200 \mathrm{~Hz}\right)$ in $\mathrm{CD}_{2} \mathrm{Cl}_{2}$, in good agreement with the resonances observed for the products of Equation 4. The electrical conductivity of a $10^{-3} \mathrm{M}$ solution of this compound in nitromethane $\left(80.1 \cdot 10^{-4} \mathrm{Ohm}^{-1} \mathrm{~m}^{2} \mathrm{~mol}^{-}\right.$ $\left.{ }^{1}\right)$ is in the expected range for $1: 1$ salts $\left(75-95 \cdot 10^{-4} \mathrm{Ohm}^{-1} \mathrm{~m}^{2} \mathrm{~mol}^{-1}\right) .^{[37]}$

\section{Equation 4}

$\mathrm{Mol}_{3}\left(\mathrm{PMe}_{3}\right)_{3}+1 / 2 \mathrm{Y}_{2} \longrightarrow\left[\mathrm{PMe}_{3} \mathrm{I}\right]\left[\mathrm{Mol}_{2} \mathrm{Y}_{2}\left(\mathrm{PMe}_{3}\right)_{3}\right]$

$(\mathrm{Y}=\mathrm{Br}, \mathrm{I})$

The presence of the iodophosphonium cation was further confirmed by ${ }^{31} \mathrm{P}$ NMR spectroscopy. The compound shows a strong and broadened resonance at $\delta 86.1\left(\mathrm{w}_{1 / 2}=78\right.$ $\mathrm{Hz}$ ) in acetone- $d_{6}$ that can be attributed to the cation. The broadening may be attributed to the effect of the paramagnetic Mo center in the counterion given that, even in the acetone- $d_{6}$ solvent, an equilibrium between free ions and ion pairs is possible. For comparison, other salts containing iodophosphonium cations exhibit resonances at $\delta 80.0\left(\mathrm{Me}_{3} \mathrm{PI}^{+} \mathrm{I}^{-}\right),{ }^{[38]} 102.4$ $\left(\operatorname{Pr}_{3}^{\mathrm{n}} \mathrm{PI}^{+} \mathrm{I}^{-}\right),{ }^{[38]}$ and $87.9\left(\operatorname{Pr}_{3}^{\mathrm{n}} \mathrm{PI}^{+} \mathrm{I}_{3}{ }^{-}\right),{ }^{[39]}$ in $\mathrm{CDCl}_{3}$. The ${ }^{31} \mathrm{P}$ resonance of the phosphine ligands in the anion cannot be observed because the anion is an octahedral complex of $\mathrm{Mo}^{\mathrm{III}}$ with $\mathrm{S}=$ 3/2. ${ }^{[36]}$ The ${ }^{31} \mathrm{P}$ NMR resonance of phosphine ligands that are coordinated to paramagnetic metal centers cannot be observed, because the spin density transmitted by the metal to the $\mathrm{P}$ nuclei relaxes too efficiently the phosphorus nuclear magnetic states. Thus, complexes $\mathrm{MoX}_{3}\left(\mathrm{PMe}_{3}\right)_{3}(\mathrm{~S}=3 / 2)$ and $\mathrm{MoX}_{4}\left(\mathrm{PMe}_{3}\right)_{3}(\mathrm{~S}=1 / 2)$ are ${ }^{31} \mathrm{P}$ NMR silent. In agreement with the literature, the cation is extremely sensitive towards moisture. Adventitious moisture leads to the development of new sharp ${ }^{31} \mathrm{P}$ NMR resonances at $\delta 2.6$ and 100.4 that are assigned, respectively, to $\mathrm{Me}_{3} \mathrm{PH}^{+}$(exchanging in acetone- $d_{6}$ to yield $\mathrm{Me}_{3} \mathrm{PD}^{+}$with $\mathrm{J}_{\mathrm{PD}}=78 \mathrm{~Hz}$ ) and to $\mathrm{Me}_{3} \mathrm{POH}^{+}$(cf. 82.7 for $\mathrm{Pr}_{3}^{\mathrm{i}} \mathrm{POH}^{+} \mathrm{I}^{-}$in $\left.\mathrm{CH}_{2} \mathrm{Cl}_{2}-\mathrm{C}_{6} \mathrm{D}_{6}\right) .{ }^{[40]}$ 
A view of the $\left[\mathrm{PIMe}_{3}\right]\left[\mathrm{MoI}_{4}\left(\mathrm{PMe}_{3}\right)_{2}\right]$ molecule is shown in Figure 13. The cation and anion are not completely separated from each other, notably the I atom of the iodophosphonium cation is at 3.4952(12) $\AA$ from atom I(4) in the tetraiodomolybdate anion. This is relevant because, according to large amount of information available in literature, the I-I distance responds in different ways upon interaction of the $\mathrm{I}_{2}$ molecule with Lewis acids and bases, leading in some cases to relatively long contacts. For instance, compounds of type $\mathrm{R}_{3} \mathrm{PI}_{2}$ display elongated I-I bonds in the solid state, e.g. 3.16(2) $\AA$ for $\mathrm{Ph}_{3} \mathrm{PI}_{2},{ }^{[41]} 3.326(1) \AA$ for $\mathrm{Bu}_{3}{ }_{3} \mathrm{PI}_{2},{ }^{[42]} 3.3394(5) \AA$ for $\left[2,6-\left(\mathrm{CH}_{3} \mathrm{O}\right)_{2} \mathrm{C}_{6} \mathrm{H}_{3}\right]_{3} \mathrm{PI}_{2},{ }^{[43]}$ and $3.408 \AA$ for $\left.\mathrm{PhMe}_{2} \mathrm{PI}_{2}{ }^{[44]}\right)$, whereas they undergo ionic dissociation in polar solvents. ${ }^{[38]}$ The I-I distance is weakened further when the negatively polarized part (the iodide ion) becomes incorporated into the $\mathrm{I}_{2}$ Lewis acid to form the $\mathrm{I}_{3}{ }^{-}$ion: $3.743(1) \AA$ in the $\left[\operatorname{Pr}_{3}{ }_{3} \mathrm{PI}\right]\left[\mathrm{I}_{3}\right]$ compound ${ }^{[40]}$ and $3.716(2)$ and 3.683(2) $\AA$ in the $\left[\left(\operatorname{Pr}_{3}^{\mathrm{i}} \mathrm{PI}\right)_{2} \mathrm{I}_{3}\right]^{+}$cation. ${ }^{[39]}$ The I-I separation in the $\left[\mathrm{PIMe}_{3}\right]\left[\mathrm{MoI}_{4}\left(\mathrm{PMe}_{3}\right)_{2}\right]$ molecule reported here is intermediate between those of the $\mathrm{R}_{3} \mathrm{PI}_{2}$ and the $\left[\mathrm{R}_{3} \mathrm{PI}\right]\left[\mathrm{I}_{3}\right]$ molecules. Thus, sequestration of the iodide ion by coordination to the $\mathrm{Mo}^{\mathrm{III}}$ has a smaller effect on the I-I distance than sequestration by $\mathrm{I}_{2}$. The P-I distance in the cation is close to that found in other $\left[\mathrm{R}_{3} \mathrm{P}-\mathrm{I}\right]^{+}$salts, e.g. $2.388(5) \AA$ in the above mentioned $\left[\left(\operatorname{Pr}_{3}^{\mathrm{i}} \mathrm{PI}\right)_{2} \mathrm{I}_{3}\right]^{+}$ cation, ${ }^{[39]}$ whereas those in the neutral $\mathrm{R}_{3} \mathrm{PI}_{2}$ compounds are longer $(>2.41 \AA)$. A structure containing the $\left[\mathrm{MoI}_{4}\left(\mathrm{PMe}_{3}\right)_{2}\right]^{-}$ion has not been previously reported. However, this ion compares rather closely with that in the $\left[\mathrm{PHPhEt}_{2}\right]\left[\mathrm{MoI}_{4}\left(\mathrm{PPhEt}_{2}\right)_{2}\right]$ structure, which also exhibits the trans stereochemistry. ${ }^{[45]}$ The $\left[\mathrm{Na}(\mathrm{THF})_{3}\right]\left[\mathrm{MoI}_{4}(\right.$ dppe $\left.)\right] \cdot \mathrm{THF}$, exhibiting the cis stereochemistry, appears to be the only other crystallographically characterized compound containing a $\left[\mathrm{MoI}_{4} \mathrm{~L}_{2}\right]^{-}$ion. ${ }^{[46]}$ The Mo-I distances are quite comparable in the two trans$\left[\mathrm{MoI}_{4} \mathrm{~L}_{2}\right]^{-}$salts. The Mo-I(4) distance is not significantly perturbed by the weak interaction with the iodine atom of the $\mathrm{Me}_{3} \mathrm{PI}^{+}$ion. The Mo-P distances, on the other hand, are slightly shorter in the $\mathrm{PMe}_{3}$ complex desribed here [2.610(3) and 2.592(2) $\AA$ for the $\mathrm{PPhEt}_{2}$ complex], 
reflecting the stronger binding ability of the $\mathrm{PMe}_{3}$ ligand. ${ }^{[45]}$ Other relevant geometrical parameters are given in the Supporting Information.

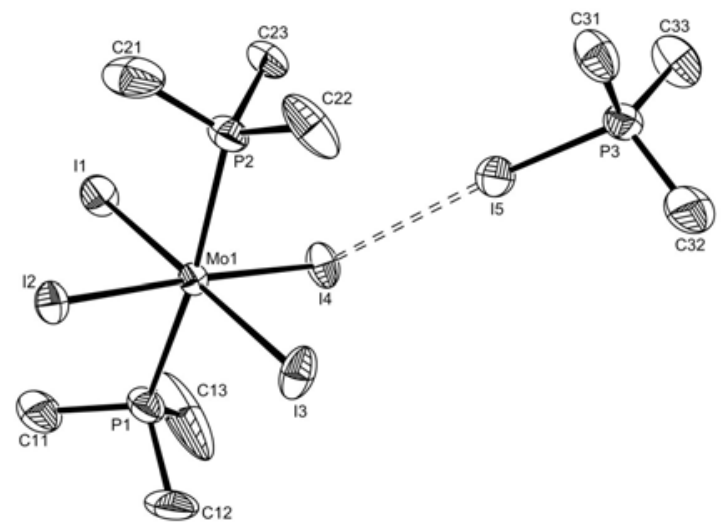

Figure 13. An ORTEP view of the $\left[\mathrm{PIMe}_{3}\right]\left[\mathrm{MoI}_{4}\left(\mathrm{PMe}_{3}\right)_{2}\right]$ molecule.

Mechanistically, the reaction in Equation 4 may be different depending on the nature of $Y_{2}$. The diiodine reagent does not have sufficient oxidizing power to remove electrons from $\mathrm{MoI}_{3}\left(\mathrm{PMe}_{3}\right)_{3}$ (see Figure 7). It is rather plausible that the reaction is triggered by a phosphine dissociation equilibrium, followed by either addition of $\mathrm{I}_{2}$ to free $\mathrm{PMe}_{3}$ with formation of the $\mathrm{PMe}_{3} \mathrm{I}_{2}$ intermediate (path $a$ in Scheme 8), or by coordinative addition of $\mathrm{I}_{2}$ to the Mo complex with formation of the $\mathrm{MoI}_{3}\left(\mathrm{PMe}_{3}\right)_{2}\left(\mathrm{I}_{2}\right)$ intermediate (path $b$ in Scheme 8), or by a concerted heterolytic activation of $\mathrm{I}_{2}$ by the $\mathrm{MoI}_{3}\left(\mathrm{PMe}_{3}\right)_{2}$ Lewis acid and the $\mathrm{PMe}_{3}$ Lewis base (path $c$ in Scheme 8). The oxidation of $\mathrm{PMe}_{3}$ by $\mathrm{I}_{2}$ to yield $\mathrm{PMe}_{3} \mathrm{I}_{2}$ is reported in the literature ${ }^{[38]}$ while complexes containing the $\mathrm{I}_{2}$ ligands have also been described. ${ }^{[47,48]}$ However, it is also possible to envisage an OSET pre-equilibrium yielding $\left[\mathrm{MoI}_{3}\left(\mathrm{PMe}_{3}\right)_{3}\right]^{+}$ and $\mathrm{I}_{2}^{-}$, the latter then rapidly rearranging to $\mathrm{I}_{3}{ }^{-}$. In that case, the iodophosphonium cation may be obtained at some stage by a reductive elimination process. When the oxidizing agent is $\mathrm{Br}_{2}$, an OSET process is definitely favorable, generating $\left[\mathrm{MoI}_{3}\left(\mathrm{PMe}_{3}\right)_{3}\right]^{+}$and $\mathrm{Br}_{3}{ }^{-}$or even $\mathrm{Br}^{-}$according to the measured redox potentials (see Figure 6 and Figure 7). Subsequently, it 
is possible that $\mathrm{PMe}_{3} \mathrm{I}^{+}$is formed again by a reductive elimination process, or that a sequence of halide exchange and electron transfer lead to $\mathrm{I}_{2}$ and $\mathrm{MoBr}_{2} \mathrm{I}\left(\mathrm{PMe}_{3}\right)_{3}$. In the latter case, the reaction would continue along the same path shown in Scheme 8 for the all-iodine system.

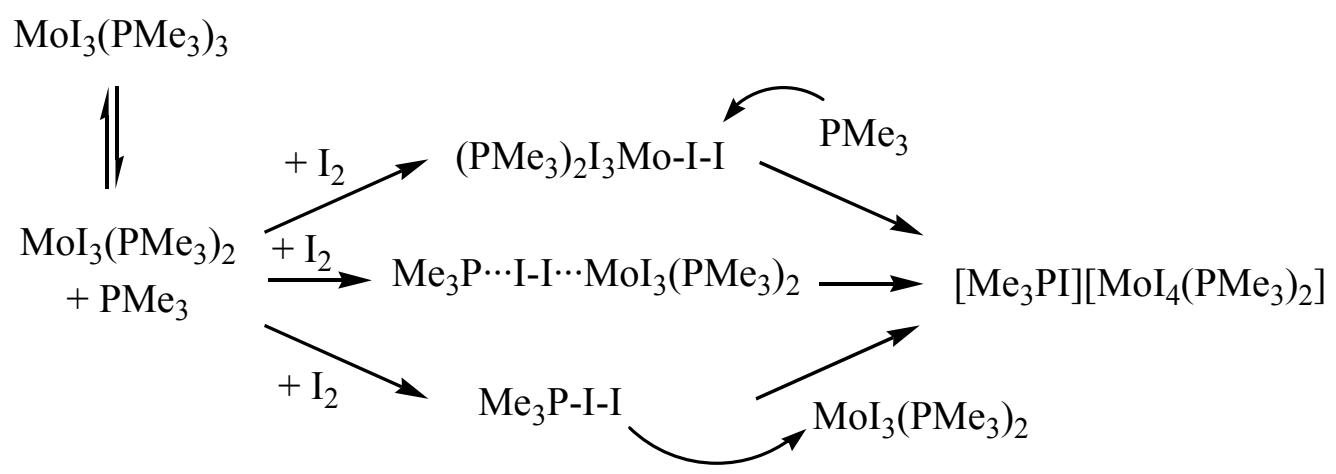

Scheme 8

It is necessary to underline that, as shown by control experiments, complex $\left[\mathrm{PIMe}_{3}\right]\left[\mathrm{MoI}_{4}\left(\mathrm{PMe}_{3}\right)_{2}\right]$ is unable to catalyze the polymerization of styrene under the same conditions in which complex $\mathrm{MoI}_{3}\left(\mathrm{PMe}_{3}\right)_{3}$ is effective (as detailed in Figure 1). Compound $\mathrm{PMe}_{3} \mathrm{I}_{2}$, obtained in situ from $\mathrm{PMe}_{3}$ and $\mathrm{I}_{2},{ }^{[38]}$ is also completely ineffective.

\section{Discussion}

All three compounds $\mathrm{MoX}_{3}\left(\mathrm{PMe}_{3}\right)_{3}(\mathrm{X}=\mathrm{Cl}, \mathrm{Br}$, I) catalyze the radical polymerization of styrene in the presence of the (1-bromoethyl)benzene initiator, to yield a "living" chain growth, although a catalyzed chain transfer competes with the chain growth process when using the triiodide catalyst. The $\mathrm{Al}\left(\mathrm{OPr}^{\mathrm{i}}\right)_{3}$ additive selectively speeds up the polymerization process, increasing its "livingness". The dihalogen oxidation studies have yielded stable tetrahalide complexes $\mathrm{MoX}_{3} \mathrm{Y}\left(\mathrm{PMe}_{3}\right)_{3}$ for $\mathrm{X}, \mathrm{Y}=\mathrm{Cl}, \mathrm{Br}$. These synthetic results are consistent with the cyclic voltammetric results and strongly suggest that these neutral 
compounds are indeed formed by atom transfer processes during the controlled/'living" polymerization of styrene. The reactions of $\mathrm{MoI}_{3}\left(\mathrm{PMe}_{3}\right)_{3}$ with $\mathrm{X}_{2}(\mathrm{X}=\mathrm{Br}, \mathrm{I})$ on the other hand, do not yield stable $\mathrm{Mo}^{\mathrm{IV}}$ complexes. This behavior, which is also consistent with the cyclic voltammetric results, clearly indicates that the putative $\mathrm{MoI}_{3} \mathrm{X}\left(\mathrm{PMe}_{3}\right)_{3}(\mathrm{X}=\mathrm{Br}, \mathrm{I})$ complexes are unstable with respect to an internal redox process to yield $\mathrm{I}_{2}$ and $\mathrm{MoI}_{2} \mathrm{X}\left(\mathrm{PMe}_{3}\right)_{3}$. Instead of metal oxidation, the interaction between $\mathrm{MoI}_{3}\left(\mathrm{PMe}_{3}\right)_{3}$ and $\mathrm{I}_{2}$ leads to phosphine oxidation and formation of an iodophosphonium salt.

The apparent inconsistency between the results in catalytic radical polymerization on one side, and the stoichiometric oxidation and electrochemical results on the other side, which is restricted to the use of the $\mathrm{MoI}_{3}\left(\mathrm{PMe}_{3}\right)_{3}$ catalyst, poses an interesting dilemma. The possibility that an alternative polymerization mechanism operates with this system does not appear likely. We must first observe that the polymer $\overline{\mathrm{M}_{\mathrm{n}}}$ grows linearly with conversion and corresponds to the theoretical value on the basis of BEB. Therefore, it is quite safe to conclude that each polymer chain originates from one BEB molecule. On this basis, anionic polymerization can immediately be excluded, because the reduction of BEB would produce radicals before producing anions. Furthermore, compound $\mathrm{MoI}_{3}\left(\mathrm{PMe}_{3}\right)_{3}$ is not a strong reducing agent. In fact, it is less reducing than the other trihalide analogues according to our electrochemical study. A cationic polymerization seems equally difficult to account for. In order to generate carbocations reversibly from $\mathrm{BEB}$, one would need to extract reversibly the bromide anion. However, $\mathrm{MoI}_{3}\left(\mathrm{PMe}_{3}\right)_{3}$ is unlikely to be a stronger Lewis acid than its trichloro and tribromo congeners. There is no indication whatsoever for the addition of even free halide ions to the 15 -electron $\mathrm{MoX}_{3}\left(\mathrm{PMe}_{3}\right)_{3}$ species. The addition of a two-electron donor to these spin quartet complexes needs an energetically costly electron pairing process, yielding a 17-electron complex with a spin doublet ground state. This phenomenon is expected to lead to an EPR active species in isotropic solutions at room temperature. While 
this indeed occurs in the presence of softer ligands $\left(\right.$ e.g. $\left.\mathrm{CpMoI}_{2}\left(\mathrm{PMe}_{3}\right)_{2}\right),{ }^{[49]}$ solutions containing $\mathrm{MoX}_{3}\left(\mathrm{PMe}_{3}\right)_{3}$ and excess $\mathrm{X}^{-}$are EPR silent. In addition, the NMR resonances of $\mathrm{MoX}_{3}\left(\mathrm{PMe}_{3}\right)_{3}$ do not decrease in intensity upon addition of $\mathrm{X}^{-}$salts. For this reason, it is even less likely that any of the three $\mathrm{MoX}_{3}\left(\mathrm{PMe}_{3}\right)_{3}$ complexes may be capable of extracting a halide ion from an organic molecule such as BEB.

Several observations are consistent with the conclusion that the three trihalide complexes are operating via the same mechanism and that this is an ATRP mechanism. As shown earlier, ${ }^{[14]} \mathrm{MoCl}_{3}\left(\mathrm{PMe}_{3}\right)_{3}$ is able to control the polymerization of styrene with both BEB and ethyl 2-bromoisobutirrate (BIB) initiator under typical ATRP conditions, to produce macromonomers containing one molecule of the bromide initiator as verified by MALDI-TOF mass spectrometry. In the same study, compound $\mathrm{MoCl}_{4}\left(\mathrm{PMe}_{3}\right)_{3}$ was shown to be an effective radical trap (controlled polymer growth under "reverse" ATRP conditions). As shown in the present study, the polymerization of styrene in the presence of each of the three $\mathrm{MoX}_{3}\left(\mathrm{PMe}_{3}\right)_{3}$ complexes, under otherwise identical conditions, yields very similar results: (i) the polymer chains grow linearly with conversion; (ii) $\overline{\mathrm{M}_{\mathrm{n}}}$ values are close to theory for a BEB-initiated polymerization; (iii) the apparent polymerization rate constants are very similar and vary monotonously $(\mathrm{Cl}>\mathrm{Br}>\mathrm{I}$, see Table 1$)$, following the trend of oxidation potentials; (iv) a very similar accelerating effect by the $\mathrm{Al}\left(\mathrm{OPr}^{\mathrm{i}}\right)_{3}$ additive is observed in the three cases.

Under the assumption that the polymerization process occurs via the ATRP mechanism also when using the $\mathrm{MoI}_{3}\left(\mathrm{PMe}_{3}\right)_{3}$ catalyst, we must argue that the product of the atom transfer, the $\mathrm{MoI}_{3} \mathrm{Br}\left(\mathrm{PMe}_{3}\right)_{3}$ complex, cannot undergo the thermodynamically favorable redox rearrangement to $\mathrm{I}_{2}$ and a mixed halide $\mathrm{Mo}(\mathrm{III})$ complex under the ATRP conditions. We can see a possible explanation for this phenomenon and, to illustrate it, we shall take an analytical approach based on homolytic bond dissociation energies (BDEs), as we have done previously. ${ }^{[4]}$ The arguments are supported by DFT calculations, which have been carried out 
on model complexes where the $\mathrm{PMe}_{3}$ ligands were replaced by $\mathrm{PH}_{3}$. The bond dissociation enthalpies of $\mathrm{PhCH}(\mathrm{Br}) \mathrm{CH}_{3}$ and $\mathrm{PhCH}(\mathrm{I}) \mathrm{CH}_{3}$ were taken from an earlier study. ${ }^{[50]}$ The results of the calculations are summarized in Figure 14. Starting from a combination of $\mathrm{MoI}_{3}\left(\mathrm{PH}_{3}\right)_{3}$ and $\mathrm{BEB}$, breaking homolytically the $\mathrm{C}-\mathrm{Br}$ bond costs $59.9 \mathrm{kcal} \mathrm{mol}^{-1}$. The trapping of the $\mathrm{Br}$ atom by the $\mathrm{Mo}(\mathrm{III})$ complex, leading to $\mathrm{MoI}_{3} \mathrm{Br}\left(\mathrm{PH}_{3}\right)_{3}$, releases $34.2 \mathrm{kcal} \mathrm{mol}^{-1}$. Thus, the $\mathrm{Br}$ atom transfer process is endothermic by $25.7 \mathrm{kcal} \mathrm{mol}^{-1}$. In the absence of an overbarrier to the atom transfer process (we have not carried out fixed-geometry calculations along the atom transfer coordinate), and assuming a negligible entropic contribution to the activation free energy, the rate constant for formation of the free radicals would be ca. $2 \times 10^{-3} \mathrm{M}^{-1} \mathrm{~s}^{-1}$ at $90^{\circ} \mathrm{C}$ according to the Eyring relationship. Since the activation entropy for the atom transfer process is most certainly negative (relative ordering of the transition state relative to the reagents), this must be considered an upper estimate. On the other hand, the bulkier $\mathrm{PMe}_{3}$ ligands will probably exert a weakening effect on the Mo-Br bond. At any rate, the DFT estimation suggests that the $\mathrm{MoI}_{3}\left(\mathrm{PMe}_{3}\right)_{3}$ complex is kinetically competent to operate as a $\mathrm{Br}$ atom acceptor in a reaction with BEB under the polymerization conditions.

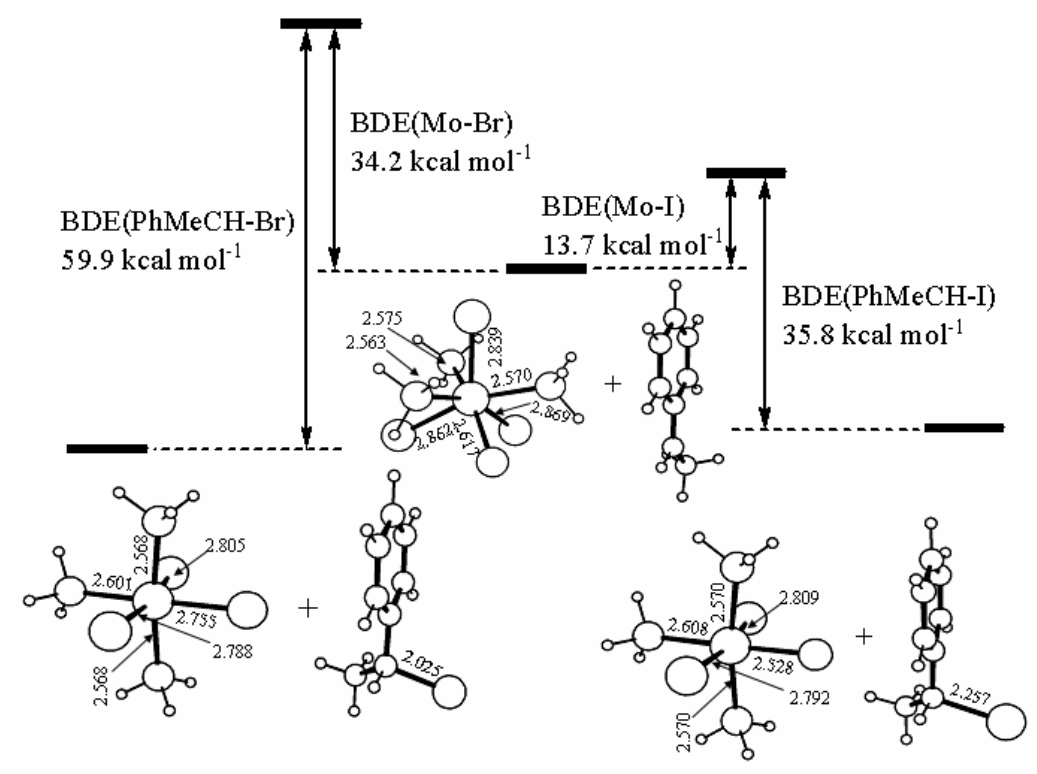


Figure 14. Relative energy and selected distances (in $\AA$ ) for different model systems, as obtained by DFT geometry optimizations.

By analyzing the reverse process, the organic radical may now extract either a $\mathrm{Br}$ or an I atom from the $\mathrm{Mo}^{\mathrm{IV}}$ complex. Rupture of the Mo-I bond costs $13.7 \mathrm{kcal} \mathrm{mol}^{-1}$, whereas formation of the $\mathrm{Ph}(\mathrm{Me}) \mathrm{CH}-\mathrm{I}$ bond releases $35.8 \mathrm{kcal} \mathrm{mol}^{-1}$. Thus, iodine atom transfer from the Mo(IV) spin trap to yield an organic iodide dormant species is exothermic by $22.1 \mathrm{kcal}$ $\mathrm{mol}^{-1}$. The mixed-halide $\mathrm{Mo}^{\mathrm{III}}$ complex is more stable when the $\mathrm{Br}$ atom occupies the position trans to a $\mathrm{PH}_{3}$ ligand and equivalent I atoms trans to each other. The stereoisomer with the $\mathrm{Br}$ atom trans to an $\mathrm{I}$ atom and the second I atom trans to a $\mathrm{PH}_{3}$ ligand is higher in energy by $0.65 \mathrm{kcal} \mathrm{mol}^{-1}$. The overall halogen exchange process is computed as endothermic by $4.8 \mathrm{kcal} \mathrm{mol}^{-1}$ [enthalpy of $\mathrm{MoI}_{2} \mathrm{Br}\left(\mathrm{PH}_{3}\right)_{3}$ and $\mathrm{Ph}(\mathrm{Me}) \mathrm{CH}-\mathrm{I}$ relative to the enthalpy of $\mathrm{MoI}_{3}\left(\mathrm{PH}_{3}\right)_{3}$ and $\left.\mathrm{Ph}(\mathrm{Me}) \mathrm{CH}-\mathrm{Br}\right]$. If this result holds true for the real $\mathrm{PMe}_{3}$ complex and for the halogen-terminated macromonomers, it would seem that the polymerization would mostly occur via bromine-terminated dormant species. This hypothesis remains to be verified experimentally by polymer end-group analysis. At any rate, this is irrelevant to the mechanistic conclusion to which we are now arriving.

The occurrence of the thermodynamically favorable redox process, leading from $\mathrm{MoI}_{3} \mathrm{Br}\left(\mathrm{PMe}_{3}\right)_{3}$ to $1 / 2 \mathrm{I}_{2}$ and a Mo ${ }^{\mathrm{III}}$ complex, requires that the $\mathrm{Mo}^{\mathrm{IV}}$ complex brakes the Mo-I bond homolytically and that two free I atoms then encounter each other. The iodine dimerization process is characterized by a high $2^{\text {nd }}$ order rate constant, ${ }^{[51,52]}$ but the process should in principle be very slow if the iodine atom concentration is very low, because of the second order rate law. This is the same principle according to which the bimolecular terminations of the radical polymer chains are unfavourable under typical ATRP conditions. A Mo-I BDE of $13.7 \mathrm{kcal} \mathrm{mol}^{-1}$, as suggested by the DFT calculations, insures that only a minor fraction of the $\mathrm{Mo}^{\mathrm{IV}}$ complex would dissociate a free I atom. In addition, the 
concentration of the $\mathrm{Mo}^{\mathrm{IV}}$ complex is itself quite low. Thus, the free I concentration under ATRP conditions should always remain lower than that of the reactive free radicals. This holds true provided that the latter are not involved themselves in a reversible trapping reaction with the Mo ${ }^{\mathrm{III}}$ complex, e.g. the SFRP equilibrium shown in Scheme 2, but the results of the styrene polymerization initiated by $\mathrm{AIBN}$ in the presence of $\mathrm{MoI}_{3}\left(\mathrm{PMe}_{3}\right)_{3}$ (Figure 2) are rather in disagreement with extensive radical trapping by $\mathrm{MoI}_{3}\left(\mathrm{PMe}_{3}\right)_{3}$. An alternative possibility is the direct bimolecular encounter of two $\mathrm{Mo}^{\mathrm{IV}}$ molecules, see Scheme 9. This process does not require the preliminary homolytic rupture of two Mo-I bonds. However: (i) it is also a bimolecular process for a species whose concentration is supposedly low under ATRP conditions; (ii) its activation barrier is likely to be greater than that associated with the halogen atom transfer to the organic radical; (iii) the activation entropy should be less favourable (more negative) relative to the atom transfer to the organic radical because of the expected higher degree of ordering in the transition state.

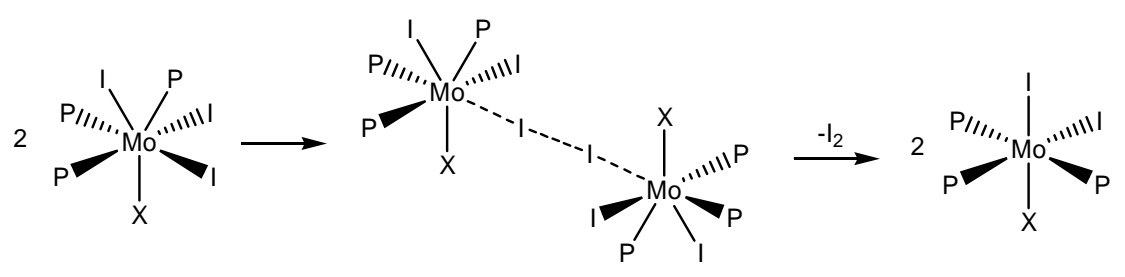

\section{Scheme 9}

In conclusion, we have described here a new mechanistic twist in atom transfer radical polymerization. By analogy with the ability of free radicals to lead to chain growth under pseudo-living conditions, rather than undergo the very favorable bimolecular, the spin trap is also capable to play its function in ATRP, i.e. take the growing radical chain back to the dormant chain, rather than undergo bimolecular decomposition processes, see Scheme 10, 
provided that the atom transfer equilibrium is sufficiently displaced toward the dormant species and ATRP catalyst.

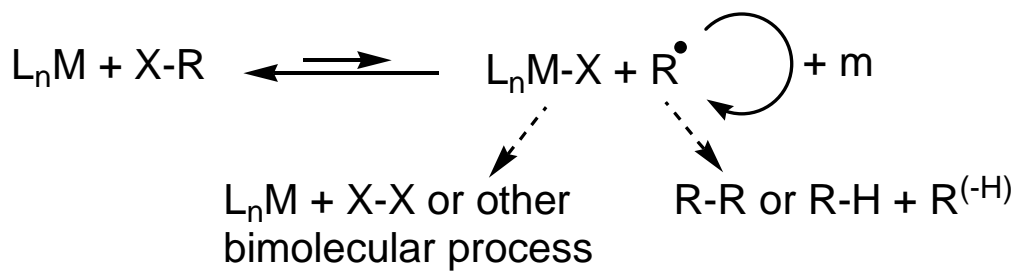

\section{Scheme 10}

\section{Conclusions}

The combination of the results of the controlled polymerization of styrene with $\mathrm{MoX}_{3}\left(\mathrm{PMe}_{3}\right)_{3}$ catalysts, the electrochemical studies of the latter complexes in the presence and absence of free $\mathrm{X}^{-}$ions, and the synthetic oxidation studies, lead us to conclude that all $\mathrm{MoX}_{3}\left(\mathrm{PMe}_{3}\right)_{3}$ complexes $(\mathrm{X}=\mathrm{Cl}, \mathrm{Br}, \mathrm{I})$ are competent ATRP catalysts for the controlled/"living" polymerization of styrene. This is true in spite of the proven thermodynamic instability of the intermediate complex (radical trap) relative to redox decomposition when iodide ligands are present. The $\mathrm{MoI}_{3} \mathrm{Br}\left(\mathrm{PMe}_{3}\right)_{3}$ complex generated during the ATRP process can exert its action as a spin trap for the growing radical chain because the bimolecular encounter of two such molecules, leading to the thermodynamically favorable generation of $\mathrm{I}_{2}$, is slower than the trapping of the growing radical chain to yield back the ATRP catalyst and the polymer dormant chain.

It is interesting to observe that this system has all the mechanistic ingredients to catalyze the radical metathesis of R-I to yield $\mathrm{I}_{2}$ plus the $\mathrm{R}$ coupling or disproportionation products, a process that is indeed thermodynamically favorable. For instance, the enthalpy changes for the reactions leading from $2 \mathrm{CH}_{3} \mathrm{X}$ to $\mathrm{C}_{2} \mathrm{H}_{6}+\mathrm{X}_{2}$ are estimated, using tabulated 
BDE values, ${ }^{[53]}$ as +21.4 for $\mathrm{X}=\mathrm{Cl},+5.7$ for $\mathrm{X}=\mathrm{Br}$ and -11.9 for $\mathrm{X}=\mathrm{I}$. For $\mathrm{R}-\mathrm{X}$ systems where $\mathrm{X}$ is $\mathrm{Cl}$ or $\mathrm{Br}$, in the presence of metal complexes $\mathrm{L}_{\mathrm{n}} \mathrm{M}$ and under conditions favoring the formation of radicals, one typically observes a one-electron oxidative addition process leading to $L_{n} M-R$ and $L_{n} M-X$ (when the $M-R$ bonds are sufficiently strong), or the formation of $L_{n} M-X$ and the $R$ coupling or disproportionation products. The stability of $L_{n} M-X$ relative to $\mathrm{L}_{\mathrm{n}} \mathrm{M}$ and $\mathrm{X}_{2}$ provides the thermodynamic driving force to homolytically split the $\mathrm{R}-\mathrm{X}$ bond. For iodide-containing $\mathrm{Mo}^{\mathrm{III}}$ complexes (which may also be generated by halogen exchange from organic iodide initiators), on the other hand, thermodynamics is against an oxidation state increase for the metal center and favors instead the oxidation of an iodide ligand to $\mathrm{I}_{2}$. The only reason why iodide-containing $\mathrm{Mo}^{\mathrm{III}}$ complexes give a well controlled "living" radical polymerization (at least for styrene), instead of catalyzing the radical metathesis of R$\mathrm{I}$, is that the low free radical concentration for both $\mathrm{R}$ and I disfavors the bimolecular recombination processes.

The new mechanistic paradigm illustrated in Scheme 10 is expected to have general validity in atom transfer radical polymerization processes, whenever the oxidized product M$\mathrm{X}$ resulting from the atom transfer process from a catalyst $\mathrm{M}$ is thermodynamically unstable with respect to bimolecular decomposition. This probably explains the ability of certain previously reported compounds to control radical polymerization, even though their oxidized partners do not appear to satisfy stability criteria from coordination chemistry first principles (see Introduction). It is pertinent to consider the role of the persistent radical effect under these circumstances. For a "normal" ATRP process (stable M-X), bimolecular terminations of the reactive radicals increase the concentration of $\mathrm{M}-\mathrm{X}$, which in turn regulates the atom transfer equilibrium. When $\mathrm{M}-\mathrm{X}$ is unstable, on the other hand, the disappearance of $\mathrm{R}$, and the consequent increase of the M-X concentration, leads to an increased spin trap bimolecular 
destruction rate. Therefore, the existence of a persistent radical effect under these circumstances must obey more stringent criteria.

Acknowledgements. We are grateful to the CNRS for financial help. FS and SM are grateful to the Conseil Régional de Bourgogne and to the CNRS for BDI fellowships. JM is grateful to the Spanish Ministerio de Educacion y Ciencia for a post-doctoral fellowship. RP thanks CINES (Montpellier) and CICT (Project CALMIP, Toulouse) for granting free CPU time.

Supporting Information Available. Description of all experimental procedures, including computational details and the X-ray structural analysis of compounds $\mathrm{MoCl}_{3} \mathrm{Br}\left(\mathrm{PMe}_{3}\right)_{3}$, $\mathrm{MoBr}_{4}\left(\mathrm{PMe}_{3}\right)_{3}, \mathrm{MoI}_{3}\left(\mathrm{PMe}_{3}\right)_{3}$ and $\left[\mathrm{PIMe}_{3}\right]\left[\mathrm{MoI}_{4}\left(\mathrm{PMe}_{3}\right)_{2}\right]$, ORTEP diagrams, a table of crystal data and refinement parameters, tables of selected bond distances and angles (total of 12 pages).

\section{References}

[1] J.-S. Wang, K. Matyjaszewski, J. Am. Chem. Soc. 1995, 117, 5614-5615.

[2] M. Kato, M. Kamigaito, M. Sawamoto, T. Higashimura, Macromolecules 1995, 28, 1721-1723.

[3] Y. Kabachii, S. Kochev, L. Bronstein, I. Blagodatskikh, P. Valetsky, Polym. Bull. 2003, 50, 271-278.

[4] E. Le Grognec, J. Claverie, R. Poli, J. Am. Chem. Soc. 2001, 123, 9513-9524.

[5] Y. Kotani, M. Kamigaito, M. Sawamoto, Macromolecules 1999, 32, 2420-2424.

[6] K. Matyjaszewski, M. Wei, J. Xia, N. E. Mcdermott, Macromolecules 1997, 30, 81618164.

[7] T. Ando, M. Kamigaito, M. Sawamoto, Macromolecules 1997, 30, 4507-4510.

[8] R. K. O'reilly, V. C. Gibson, A. J. P. White, D. J. Williams, J. Am. Chem. Soc. 2003, 125, 8450-8451.

[9] G. Moineau, C. Granel, P. Dubois, R. Jérôme, P. Teyssié, Macromolecules 1998, 31, 542-544.

[10] C. Granel, P. Dubois, R. Jérôme, P. Teyssié, Macromolecules 1996, 29, 8576-8582.

[11] P. Lecomte, I. Draiper, P. Dubois, P. Teyssié, R. Jérôme, Macromolecules 1997, 30, 7631-7633.

[12] F. Stoffelbach, R. Poli, P. Richard, J. Organometal. Chem. 2002, 663, 269-276. 
[13] F. Stoffelbach, D. M. Haddleton, R. Poli, Eur. Polym. J. 2003, 39, 2099-2105.

[14] F. Stoffelbach, J. Claverie, R. Poli, C. R. Acad. Sci. Paris C 2002, 5, 37-42.

[15] R. D. Rogers, E. Carmona, A. Galindo, J. L. Atwood, L. G. Canada, J. Organomet. Chem. 1984, 277, 403-415.

[16] L. Manojlovic-Muir, J. Chem. Soc., Dalton Trans. 1976, 1976, 192-195.

[17] K. Matyjaszewski, J. H. Xia, Chem. Rev. 2001, 101, 2921-2990.

[18] L. Tang, J. Norton, Macromolecules 2004, 37, 241-243.

[19] H. Fischer, Macromolecules 1997, 30, 5666-5672.

[20] T. Ando, M. Kamigaito, M. Sawamoto, Macromolecules 2000, 33, 6732-6737.

[21] Y. Kotani, M. Kamigaito, M. Sawamoto, Macromolecules 1999, 32, 6877-6880.

[22] H. Uegaki, Y. Kotani, M. Kamigaito, M. Sawamoto, Macromolecules 1997, 30, 22492253.

[23] J. Guo, Z. Han, P. Wu, J. Mol. Catal. A 2000, 159, 77-83.

[24] M. Kamigaito, T. Ando, M. Sawamoto, Chem. Rev. 2001, 101, 3689-3745.

[25] J. Qiu, K. Matyjaszewski, L. Thouin, C. Amatore, Macromol. Chem. Phys. 2000, 201, 1625-1631.

[26] Two distinct oxidation processes are observed for $\mathrm{X}=\mathrm{Br}$ because of the potential range of stability for the $\mathrm{Br}_{3}{ }^{-}$species.

[27] F. Stoffelbach, D. Saurenz, R. Poli, Eur. J. Inorg. Chem. 2001, 2699-2703.

[28] J. R. Moss, B. L. Shaw, J. Chem. Soc. (A) 1970, 595-601.

[29] M. Drew, A. Wolters, J. Wilkins, Chem. Commun. 1972, 1278-1279.

[30] Weak ${ }^{1} \mathrm{H}$ NMR resonances that are characteristic of the $\left[\mathrm{MoX}_{4}\left(\mathrm{PMe}_{3}\right)_{2}\right]^{-}$complexes ${ }^{[31]}$ developed over several hours at room temperature.

[31] R. Poli, J. C. Gordon, Inorg. Chem. 1991, 30, 4550-4554.

[32] F. A. Cotton, G. Wilkinson, Advanced Inorganic Chemistry, 5th ed., Wiley, New York, 1988.

[33] J. U. Desai, J. C. Gordon, H.-B. Kraatz, V. T. Lee, B. E. Owens-Waltermire, R. Poli, A. L. Rheingold, C. B. White, Inorg. Chem. 1994, 33, 3752-3769.

[34] J. C. Gordon, S. P. Mattamana, R. Poli, P. E. Fanwick, Polyhedron 1995, 14, 13391342.

[35] F. Calderazzo, R. Poli, P. F. Zanazzi, Gazz. Chim. Ital. 1988, 118, 595-601.

[36] J. C. Fettinger, J. C. Gordon, S. P. Mattamana, C. J. O'connor, R. Poli, G. Salem, Inorg. Chem. 1996, 35, 7404-7412.

[37] W. J. Geary, Coord. Chem. Rev. 1971, 7, 81-122.

[38] N. Bricklebank, S. M. Godfrey, A. G. Mackie, C. A. Mcauliffe, R. G. Pritchard, P. J. Kobryn, J. Chem. Soc., Dalton Trans. 1993, 101-103.

[39] W. I. Cross, S. M. Godfrey, C. A. Mcauliffe, R. G. Pritchard, J. M. Sheffield, G. M. Thompson, J. Chem. Soc., Dalton Trans. 1999, 2795-2798.

[40] F. Ruthe, P. G. Jones, W. W. Du Mont, P. Deplano, M. L. Mercuri, Z. Anorg. Allg. Chem. 2000, 626, 1105-1111.

[41] S. M. Godfrey, D. G. Kelly, C. A. Mcauliffe, A. G. Mackie, R. G. Pritchard, S. M. Watson, J. Chem. Soc., Chem. Comm. 1991, 1163-1164.

[42] W. W. Du Mont, M. Baetcher, S. Pohl, W. Saak, Angew. Chem. 1987, 99, 945-947.

[43] S. M. Godfrey, C. A. Mcauliffe, R. G. Pritchard, J. M. Sheffield, J. Chem. Soc., Dalton Trans. 1998, 1919-1923.

[44] N. Bricklebank, S. M. Godfrey, H. P. Lane, C. A. Mcauliffe, R. G. Pritchard, J.-M. Morenao, J. Chem. Soc., Dalton Trans. 1995, 2421-2424.

[45] F. A. Cotton, R. Poli, Inorg. Chem. 1986, 25, 3624-3629.

[46] S. P. Mattamana, R. Poli, Inorg. Chim. Acta 1995, 229, 55-60. 
[47] R. Makiura, I. Nagasawa, N. Kimura, S. Ishimaru, H. Kitagawa, R. Ikeda, Chem. Commun. 2001, 1642-1643.

[48] R. A. Gossage, A. D. Ryabov, A. L. Spek, D. J. Stufkens, J. A. M. Van Beek, R. Van Eldik, G. Van Koten, J. Am. Chem. Soc. 1999, 121, 2488-2497.

[49] S. T. Krueger, R. Poli, A. L. Rheingold, D. L. Staley, Inorg. Chem. 1989, 28, 45994607.

[50] M. B. Gillies, K. Matyjaszewski, P.-O. Norrby, T. Pintauer, R. Poli, P. Richard, Macromolecules 2003, 36, 8551-8559.

[51] M. I. Christie, R. G. W. Norrish, G. Porter, Proc. Roy. Soc. (London) 1953, 216A, 152-165.

[52] G. Porter, Proc. Roy. Soc. (London) 1950, A200, 284-300.

[53] Y.-R. Luo, Handbook of Bond Dissociation Energies in Organic Compounds, CRC Press, Cleveland, Ohio, 2002. 
Table 1. Apparent rate constants for styrene polymerization. ${ }^{\mathrm{a}}$ Polymerization conditions are as shown in Figure 1 and Figure 3.

\begin{tabular}{lccc} 
Complex & $k_{\text {app }} / \mathrm{min}^{-1}$ & $k_{\text {app }}{ }^{\mathrm{Al}} / \mathrm{min}^{-1}$ & $k_{\text {app }}{ }^{\mathrm{Al}} / k_{\text {app }}$ \\
\hline $\mathrm{MoCl}_{3}\left(\mathrm{PMe}_{3}\right)_{3}$ & $1.42 \cdot 10^{-4}$ & $4.72 \cdot 10^{-4}$ & 3.33 \\
$\mathrm{MoBr}_{3}\left(\mathrm{PMe}_{3}\right)_{3}$ & $5.49 \cdot 10^{-5}$ & $5.02 \cdot 10^{-4}$ & 9.14 \\
$\mathrm{MoI}_{3}\left(\mathrm{PMe}_{3}\right)_{3}$ & $3.57 \cdot 10^{-5}$ & $4.41 \cdot 10^{-4}$ & 12.33 \\
\hline
\end{tabular}

${ }^{\mathrm{a}} k_{\text {app }}=$ apparent rate constant in the absence of $\mathrm{Al}(\mathrm{OiPr})_{3}$ co-catalyst (polymerization conditions as in Figure 1). $k_{\text {app }}{ }^{\mathrm{Al}}=$ apparent rate constant in the presence of $\mathrm{Al}(\mathrm{OiPr})_{3}$ cocatalyst (polymerization conditions as in Figure 3). 
TOC graphic

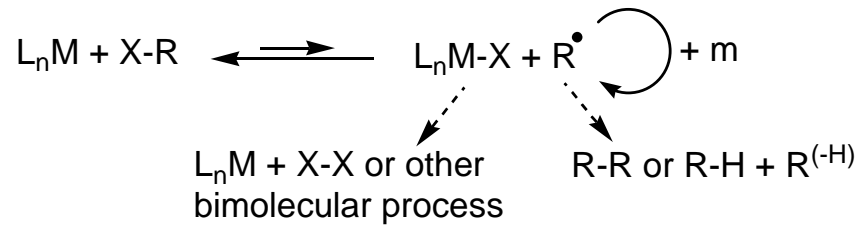

